\title{
MÉXICO: DE EPICENTRO A PERIFERIA. \\ LA DESINTEGRACIÓN DEL MODELO SEMIINFORMAL DEL COMERCIO HISPANOAMERICANO (1750-1840)
}

\author{
Mariano Bonialian \\ El Colegio de México
}

ANTECEDENTES: MÉXICO Y SU CENTRALIDAD

EN EL COMERCIO IMPERIAL (1580-1740)

$\mathrm{Z}$ trabajos previos formulamos las principales características de lo que denominamos el modelo semiinformal de comercio hispanoamericano que funcionó durante dos periodos históricos concretos: $1580-1640$ y $1680-1740 .{ }^{1}$ Lo presentamos como un tejido que combinaba flujos lícitos e ilegales y que, de manera simultánea, se aprovechó y condicionó el monopolio español sobre el comercio trasatlántico. Expusimos la manera en que México cumplió un papel centralizador en el esquema, al ser el "corazón” de la

Fecha de recepción: 15 de marzo de 2016 Fecha de aceptación: 17 de junio de 2016

${ }^{1}$ Bonialian, "México", pp. 7-30; Bonialian, China en la América, pp. 27-82. 
red, punto de confluencia de los tres flujos más trascendentes para la integración económica de Hispanoamérica en el imperio español durante la temprana globalización. Dos de esos circuitos fueron oficiales e interoceánicos, mientras que el tercero resultó ilícito e intercolonial. En el primer grupo aparecía la conexión trasatlántica de la flota española que unía el puerto de Cádiz con el de Veracruz y, por el otro lado, el eje transpacífico, que enlazaba a las islas Filipinas con el puerto de Acapulco mediante el galeón de Manila. Brindamos pruebas del notable fraude practicado por ambos conductos, sobrepasando los límites oficiales de exportación de metálico hacia China y Europa y de importación de bienes hacia Nueva España. Los ingresos de mercancías asiáticas y europeas que promovieron a conciencia los grandes comerciantes de la Ciudad de México generaron no sólo una respuesta a la demanda del mercado interno, sino también un excedente, posicionando a la capital novohispana como el principal almacén, depósito y punto de redistribución para los productos extranjeros por toda Hispanoamérica.

La dinámica de ambos circuitos de larga distancia y la gran concentración de sus bienes en la Ciudad de México resultaron ser la "chispa" para la creación de un flujo entre México y Perú por el Pacífico, constituyendo el tercer circuito del modelo. Así, navíos peruanos se movilizaron hacia la costa novohispana para adquirir los productos europeos y asiáticos a precios más bajos que los ofrecidos por la vía oficial de los galeones de Portobelo. En el intercambio, los peruanos les entregaban a los novohispanos plata, azogue, cacao, aceite y vinos. Vale señalar que la reexpedición de efectos extranjeros también fue una realidad del circuito 
del Caribe, desde Veracruz hacia Cartagena y Portobelo. ${ }^{2}$ Pero el gran desarrollo del contrabando europeo por el área del Caribe, más la presencia del galeón español, contribuyeron a que la ruta de bienes ultramarinos hacia Cartagena fuera relativamente delgada, sin alcanzar la intensidad que sí adquirió la vía del Pacífico. ${ }^{3}$ En el mapa 1 (p. 91) se ejemplifica el funcionamiento del modelo mercantil colonial con epicentro en la Ciudad de México. El capitán francés Jean de Monségur en sus Nuevas memorias de 1709 brinda una notable síntesis de lo reseñado hasta aquí:

Resultaría grato al lector que se aclarara cómo es posible que tantas mercaderías de Asia puedan consumirse en México, lo que satisfaremos diciendo que, cuando hay más de lo necesario para el consumo de México o las mercaderías están a precios bajos, se despachan para el Perú por la vía de la Mar del Sur; y aunque este comercio está severamente prohibido, esto no impide que, mediante negociación secreta, se pasen con seguridad, libre y decididamente, todas las mercancías que son tan estimadas en el Perú como en México. Cada año no dejan de llegar a las costas de México algunas naves del Perú en espera del galeón de Manila, a fin de hacer compras de las mercancías que trae. Ocurre a menudo que compren también de las de Europa, cuando escasean en el Perú y están a precios razonables en México. A México llevan cacao de Guayaquil con mucha plata en monedas y barras. Este comercio que allí se hace a pesar de estar terminantemente prohibido por las leyes,

2 Bonialian, "La contratación de la China", pp. 11-41.

${ }^{3}$ Sobre la problemática del contrabando por el Atlántico sur en la época colonial véase SuÁrez, Desafíos transatlánticos; VILA Vilar, "Las ferias", pp. 275-340; Moutoukias, Contrabando. 
es un buen negocio, y resulta de gran provecho para los virreyes y otros ministros del Rey. ${ }^{4}$

Presenciamos un esquema de intercambio de larga duración, protegido por las autoridades políticas mexicanas y peruanas con capacidad para condicionar el régimen español trasatlántico. La protección política para el libre desenvolvimiento de los agentes mercantiles permitió que el comercio por el Pacífico adquiriera autonomía, repercutiendo en los ciclos de los grandes flujos que se desarrollaron por el otro gran océano. El movimiento de bienes y plata entre México y Perú provocó un doble efecto sobre la Carrera de Indias: a) otorgó mayor impulso al comercio de flotas por Veracruz, ya que una porción de los bienes europeos que ingresó por sotavento, transitó hacia la Ciudad de México y tomó rumbo hacia el Perú a través del Mar del Sur; $b$ ) contribuyó a recurrentes crisis en los galeones de Portobelo (1580-1630), hasta hacerlos desaparecer un siglo después (1740). ${ }^{5}$ Todos los agentes económicos participaron con plena conciencia para que el gran modelo mercantil con “cabeza” en la Ciudad de México funcionara, incluso los cargadores españoles que mostraron desinterés en las ferias sudamericanas priorizaron los intercambios con México. Estos elementos, junto con otros más, nos permitieron definir al Pacífico como un lago indiano, con gran dosis de independencia económica y autonomía, muy lejos de la noción de Spanish Lake

\footnotetext{
${ }^{4}$ Monségur, Las nuevas memorias, p. 219.

${ }^{5}$ Las contracciones mercantiles en Portobelo a raíz del tráfico por el Pacífico entre México y Perú fueron una constante desde 1580 y durante las primeras décadas del siglo siguiente. VILA VILAR, "Las ferias"; BonIALIAN, "La ropa de la China" [en prensa].
} 
propuesto por reconocidos estudios. ${ }^{6}$ Insistíamos en que el Pacífico contó, hasta la primera mitad del siglo xviıI, con una identidad hispanoamericana, porque los comerciantes de la Ciudad de México y de Lima fueron los agentes que dinamizaron la vida mercantil por el Pacifico.

Considerando estos antecedentes, el presente ensayo tiene el propósito de identificar las razones que contribuyeron a la desaparición de este tejido comercial. Estamos lejos de presentar aquí un nuevo y acabado esquema comercial constituido en Hispanoamérica a partir de 1750, problemática de notable magnitud e imposible de sintetizar en un breve ensayo. Pero si el propósito es reconocer los factores que provocaron la desintegración del esquema mercantil que funcionó hasta 1740, necesariamente debemos atender los "hilos" más elementales de la nueva "telaraña" que, a partir de esos años, se fue constituyendo a nivel continental y global. La interpretación histórica que aquí presentamos sobre el comercio hispanoamericano a escala continental y global sólo fue posible al tomar como referencia y de consulta permanente tanto los estudios dedicados a los cambios económicos y políticos ocurridos en regiones y virreinatos durante las reformas borbónicas, como a los trabajos de política económica que bajo un abordaje de Estado-nación se ocuparon del periodo de las emancipaciones iberoamericanas. ${ }^{7}$

\footnotetext{
6 Schurz, "The Spanish Lake”, pp. 181-194; Spate, The Pacific; Mola y Martínez Shaw, "El Galeón de Manila”, pp. 58-65; Bernabeu, El Pacífico ilustrado.

7 Sería injusto citar aquí la enorme lista de los trabajos consultados. El lector podrá encontrar en el apartado final de bibliografía las investigaciones consideradas en el armado del presente ensayo.
} 
Un abanico de preguntas puede servir como punto de partida para el análisis. ¿Cuáles fueron las causas que provocaron cambios estructurales en los circuitos imperiales y globales en torno a Hispanoamérica a partir de 1750, para provocar la pérdida de la centralidad de México, de punto de confluencia para los contactos con Asia, Europa y Sudamérica? ¿Qué identidad cobró el Pacífico novohispano si notamos que los agentes de Lima y de la Ciudad de México perdieron protagonismo en el área marítima? ¿Podemos seguir sosteniendo la definición de lago indiano, autónomo, más vinculado al espacio asiático que al europeo en el contexto de una globalización policéntrica ${ }^{8} \mathrm{o}$, por el contrario, ¿el Pacífico se verá envuelto y condicionado por la revolución del comercio y consumo promovido por las potencias europeas, en particular por Gran Bretaña y Estados Unidos, en un contexto de expansión del liberalismo económico? ¿Qué transformaciones ocurrieron hacia 1750 en las relaciones directas entre Asia e Hispanoamérica para que el galeón de Manila decayera en la función trascendental que cumplía en el modelo mercantil colonial? El ensayo es un primer acercamiento a estas grandes problemáticas, sabiendo que cada una de ellas merecería un estudio independiente.

El punto de partida temporal será 1750 , fecha en que se manifiestan señales de la situación terminal del tejido mercantil que sitúa al Pacífico y a México como centro. ¿Cuáles serían esas señales?: a) la apertura peninsular de la vía del Cabo de Hornos para alcanzar los mercados del Pacífico

${ }^{8}$ Aquí compartimos las ideas propuestas por Findlay y O’Rourke, quienes califican de policéntrica a la economía global anterior a 1800, donde China y la India cumplieron un papel protagónico como espacios productores de bienes y circulación de metálico. Findlay y O’Rourke, Power and Plenty. 
hispanoamericano y China, dado el fin del sistema de galeones por Portobelo; $b$ ) la crisis del galeón, con la consecuente desaparición del entronque de bienes extranjeros desde Acapulco hacia el Perú; c) el paquete de medidas borbónicas para un "libre comercio" entre Europa e Hispanoamérica y $d$ ) el dominio y penetración de la economía europea en los mercados hispanoamericanos, proceso que podríamos denominar la "atlantización" de la economía pacífica americana.

Ahora bien, si el objeto es analizar cada uno de los factores que llevaron a la descomposición del modelo comercial colonial, necesariamente se debe extender el análisis a las primeras décadas del siglo XIx. La mayoría de los procesos que ocasionan la crisis de la centralidad mercantil mexicana no parecen detenerse ni en las vísperas, ni en el momento en que se produce la independencia del Estado mexicano. El suceso de emancipación política vendría, más bien, a profundizar el papel de periferia de México en la economía internacional; un proceso que, insistimos, se habría iniciado con las reformas borbónicas. Entonces, ¿por qué el ensayo presenta como fecha de cierre el año 1840? La mayor parte de los factores que contribuyeron a la caída del modelo comercial que colocó a la Ciudad de México como centro continuaron su desarrollo hasta esa fecha. A mediados del siglo xIX, reinará una nueva estructura comercial que envolverá al Pacífico mexicano en su función de espacio mediador de Europa, Panamá y San Francisco. La nueva red estará propiciada, en gran medida, por la fiebre de oro de California (1840) y la construcción de la vía férrea por el istmo de Panamá (1855). ${ }^{9}$

${ }^{9}$ El análisis de este nuevo tejido comercial supera los propósitos del ensayo. Vale mencionar que, a partir de entonces, el Pacífico mexicano, que 


\begin{tabular}{|c|c|}
\hline Periodo & $\begin{array}{l}\text { El Pacífico y los ejes transoceánicos americanos de la } \\
\text { economía global }\end{array}$ \\
\hline $1565-1740$ & $\begin{array}{l}\text { China-Filipinas-Acapulco-El Callao-Ciudad de México- } \\
\text { Veracruz-España }\end{array}$ \\
\hline $1750-1850$ & $\begin{array}{l}\text { Europa-Buenos Aires-Cabo de Hornos-Chile-Perú- } \\
\text { Pacífico mexicano-California-China }\end{array}$ \\
\hline 1850 & $\begin{array}{l}\text { Europa-Estados Unidos-Colón-Ciudad de Panamá- } \\
\text { Pacífico mexicano-San Francisco-China }\end{array}$ \\
\hline
\end{tabular}

La periodicidad propuesta ilustrada en el presente cuadro permitirá al lector inscribir nuestras hipótesis en el contexto de una larga duración de la historia del Pacífico y del comercio global. Pasemos, en suma, a analizar cada una de las razones que explicarían la desaparición del modelo comercial con centralidad mexicana, las que deben interpretarse en su continua relación.

\section{LA CRISIS DEL GALEÓN DE MANILA}

Y DEL ENTRONQUE MERCANTIL ACAPULCO-PERÚ

La historiografía considera dos hechos para explicar el golpe de gracia que sufrió el comercio del galeón de Manila en la segunda mitad del siglo xviri. Por un lado, se dice que su crisis se inició con la captura en 1743 de los tesoros en plata de la nao Covadonga por el pirata inglés Anson. ${ }^{10}$ En 1762

contará con Mazatlán como puerto nodal, se subsume a un nuevo eje de la economía mundial, reemplazando, o más bien desplazando, el derrotero transcontinental por el Cabo de Hornos como punto interoceánico dominante. Busto Ibarra, "El espacio del Pacífico". Sobre la evolución de San Blas durante el siglo xix, véase Contreras Valdez, Nayarit.

${ }_{10}$ Desde 1766 hasta 1780, Manuel García fue obispo del Convento de San Esteban de las islas Filipinas, en AGI, Filipinas, 1029, N.13, s/n 
se desencadenó la invasión a Manila por parte de Inglaterra, lo cual, según los estudiosos, agudizó la decadencia del eje transpacífico. El control inglés habría generado creciente desinterés en la inversión de capitales en el galeón. ${ }^{11}$ Sin menospreciar los sucesos relatados, nos resulta apresurado concebirlos como explicaciones estructurales de la crisis de la nao de China durante el transcurso de la segunda mitad del siglo XviII, una crisis que se prolongó hasta su desaparición en $1815 .^{12}$

La institucionalización del eje mercantil del Cabo de Hornos contribuyó para que el galeón de Manila no gozara del auge que lo caracterizó en tiempos precedentes. Ya veremos los motivos de esta relación. Interesa ahora atender otra de las causas: la presencia de nuevos agentes y corporaciones peninsulares en el trato transpacífico, cuestionando el dominio de los comerciantes novohispanos en el área. A partir de 1760, en un contexto de medidas de libre comercio, compañías de origen peninsular comenzaron a importar bienes asiáticos a los puertos occidentales hispanoamericanos. El propósito era claro: adquirir cantidades de monedas de plata que se producían, como en sus mejores épocas,

de fs. En su Representación del comercio señala que Anson logró captu$\operatorname{rar} 3500000$ en plata que salieron desde Acapulco hacia Manila. AHCJS, film 220, GARcía, Representación del comercio, f. 6. Agradezco al doctor Jean Sánchez por brindarme el acceso al documento del obispo.

11 Álvarez, “El impacto”, pp. 206-207; Yuste, Emporios, pp. 149-150.

12 Contamos con un documento que expresa la suspensión del galeón de Manila en septiembre de 1813 y el permiso para realizar comercio con China con barcos particulares entre Filipinas, Acapulco y San Blas; véase AGN, Instituciones coloniales, Reales Cédulas originales, vol. 209, exp. 166, fs. 1 . 
en el Perú y en Nueva España. ${ }^{13}$ Las nuevas corporaciones compitieron exitosamente con los intereses novohispanos depositados en el comercio del galeón, provocando la disminución de los volúmenes de importación de bienes y exportación de metálico. Entre las corporaciones mercantiles españolas que se fundaron para el trato transpacífico, sin duda la Real Compañía de Filipinas, fundada en 1785, fue la más trascendente. ${ }^{14}$

Durante la segunda parte del siglo xviII, el puerto novohispano de San Blas y el limeño de El Callao fueron formalmente autorizados a participar en el comercio asiático, rompiendo con la exclusividad de puerto único de Acapulco. Conforme avanzaba la segunda mitad del siglo, San Blas se fue convirtiendo en el puerto elegido para el arribo de los barcos de las compañías españolas o de la propia nao de China. La presencia peninsular, que iniciaba el desplazamiento de los novohispanos en el control del comercio transpacífico, deterioró el papel central de Acapulco, llevando a su feria a situaciones de decadencia. Su poder de irradiación como exclusivo punto redistribuidor de bienes asiáticos hacia el interior del virreinato y hacia el mercado peruano perdía significancia. De ahora en más, ni el

${ }^{13}$ Los estudios reconocen que la producción de plata americana registró un auge durante la segunda mitad del siglo xviII. En la primera mitad de la centuria, Perú continuaba registrando un estancamiento en su producción, que repunta en las décadas finales. Nueva España tomará la vanguardia como espacio productor metalífero del mundo hacia 1770 . Véase Cross, "South American", p. 403.

${ }^{14}$ Las empresas restantes eran las siguientes: la línea de los navíos de guerra El Buen Consejo y Venus (1765), la compañía de los Cinco Gremios Mayores de Madrid (1776), y Uztáriz, San Ginés y Compañía, que nació en 1779 con su navío el Hércules. 
galeón de Manila ni el puerto de Acapulco serán elementos exclusivos del trato transpacífico. Las propias compañías mercantiles peninsulares por el Pacífico, la flota de Veracruz que estará en actividad hasta 1789 y los navíos de registro que operaban por la costa del Atlántico comenzaron a realizar la importación de tejidos, loza y otros productos del Oriente para el consumo novohispano.

En Acapulco reinará un estado de inestabilidad económica, generada por situaciones contrapuestas: suspensión de ferias, galeones semivacíos o, por el contrario, sobrecargados que no respondían a las demandas de un mercado que operaba, de entonces en adelante, a un ritmo acelerado bajo las pautas de la política de "libre comercio". En 1767, el contador general de Indias, Tomás Ortiz de Landazuri ofrecía señales negativas del galeón: "la nao de Filipinas no produce por sí ni puede la introducción de ropas de China al Perú ni Tierra firme; que por el contrario aún no presta las necesarias para los parajes adonde vienen destinadas a México". ${ }^{15}$

Por su parte, Manuel García señala que "[...] en el año 86 salió de Manila el navío San Andrés con dos millones de pesos de principal: el año siguiente salió el San Joseph con otra carga más interesada y ninguno de los dos hicieron feria, ya por lo exorbitante de sus cargas o ya por estar abastecido el reino de México con motivo del libre comercio". ${ }^{16}$

La ruta Acapulco-Ciudad de México ya no será el único derrotero posible para la comercialización de los bienes asiáticos. La apertura portuaria y sus conexiones directas al trato asiático permitieron que los mercados y los comerciantes

15 Navarro García, "El comercio", p. 41.

16 AHCJS, film 220, García, Representación, f. 7. 
regionales del interior relajaran la subordinación con la Ciudad de México. El caso más representativo de la pérdida de fuerza del eje Acapulco-Ciudad de México fue la constitución de la red espacial y de agentes que se configuró en torno a San Blas, Tepic y la ciudad de Guadalajara en la movilización de los productos asiáticos. ${ }^{17}$ En otros términos, la función de la Ciudad de México como almacén, depósito y centro redistribuidor de los bienes asiáticos ya no operará a plenitud.

Si el galeón de Manila perdía incidencia en la economía mexicana, mucho más lo hará sobre la realidad del Perú. La ciudad principal del espacio peruano, Lima, llegó a ser calificada por un funcionario de la época como la "feria de Pekín”, por la gran distribución y consumo de tejidos y sedas orientales que se deslizaban, como una suerte de cascada, desde el puerto guerrerense. ${ }^{18}$ La definición no podría representar el escenario que desde 1750 vivieron tanto Lima como el conjunto del espacio hispanoamericano. Una sencilla razón lo confirmaría: desde 1750 prácticamente desaparecieron las reexportaciones ilícitas de bienes orientales - y también europeos - desde Acapulco hacia el puerto del Callao. Uno de los “nervios principales” del lago indiano (la orientación norte sur de productos extranjeros) se extinguió completamente. Sabemos que entre los años 1670 y 1740, se dirigieron más de 80 embarcaciones limeñas con plata, azogue, cacao y vino a los puertos del Pacífico mexicano. Veinticinco de ellos - cifra oficial, que no refleja el contraflujo- regresaron por contrabando y cargados con mercadería

17 IBARra, "Redes de circulación”, pp. 1017-1041.

18 Bonialian, El Pacífico, p. 347. 
local, asiática, europea y de Castilla, a los puertos del Callao, Guayaquil y Paita. ${ }^{19}$ Lo sorprendente es que, apenas iniciada la segunda mitad del siglo xvin, el flujo desde México hacia el Perú por el Pacífico no continuó en lo más mínimo. ${ }^{20}$

Los estudios dedicados al comercio entre México y Perú durante el periodo tardocolonial confirman el crecimiento en la comercialización de cacao guayaquileño para el consumo de la plaza novohispana. ${ }^{21}$ El tráfico del grano ecuatoriano hacia México se veía apoyado e impulsado por la política comercial borbónica de 1774 para la absoluta libertad en la circulación de bienes de producción local entre ambos virreinatos. ${ }^{22}$ Pero lo que más llama la atención es que a pesar del auge del comercio del grano de sur a norte, no hemos encontrado ni un solo caso de retorno ilegal de bienes asiáticos y europeos. Es muy posible que, si nos esforzamos en la búsqueda de documentos, al fin de cuentas logremos encontrar

19 Bonialian, El Pacífico, pp. 302-303.

20 Es necesario indicar que el modelo que posicionó a la Ciudad de México como centro comercial hasta la primera mitad del siglo se legalizó entre 1779 y 1784. El bloqueo atlántico producido por el conflicto entre España e Inglaterra en el marco de la independencia estadounidense obligó a la corona borbónica a autorizar las operaciones de reexpedición de bienes chinos y europeos desde el Pacífico mexicano hacia el Perú. Pero hay que subrayar que durante esos años la ruta del Cabo de Hornos estuvo clausurada, obligando a que, en una coyuntura excepcional, se lograra reconstruir aquel tejido. Bonialian, El Pacífico, pp. 420-422 y 426-441. 21 Existe abundante literatura sobre la problemática. Los trabajos más representativos serían los de LEón DE BORJA y SzÁsdi, "El comercio”, pp. 1-50; Miño Grijalva, El cacao Guayaquil; Contreras, El sector exportador.

22 AGN, Instituciones coloniales, Reales cédulas, vol. 104, exp. 10, fs. 1-5; AGN, Instituciones coloniales, Indiferente virreinal, c. 2790, exp. 10, fs. 1-8. 
algún hecho aislado de contrabando. Pero la dificultad en encontrar testimonios nos indica, ante todo, que el circuito comercial ilícito desde la costa occidental novohispana hacia el Perú, al menos, descendió significativamente. Muchas de las premisas sostenidas por Humboldt en su Ensayo político han sido cuestionadas, con razón, por la historiografía. Pero su testimonio debe ser atendido cuando sostuvo que el comercio de Acapulco hacia Guayaquil y Lima fue "casi nulo", reducido a "géneros de lana de las fábricas de Querétaro, un poco de grana y a mercancías de las Grandes Indias". ${ }^{23}$ En cuanto a nuestro rastreo, recién después de 1770 se identificaron casos de importación de bienes asiáticos en los puertos del Perú. Pero las embarcaciones que lo promovieron no llegaron a la costa peruana desde el Pacífico mexicano, sino con procedencia directa de Cantón, gracias a la navegación de las compañías peninsulares o, como se explicará en las páginas siguientes, de navíos europeos desde el Atlántico. Desde 1750 las mercaderías asiáticas y europeas que se consumieron desde Panamá hasta las regiones más australes del continente ya no provenían de México, sino de Europa, vía el Atlántico.

En efecto, el tráfico de mercaderías europeas entre México y Perú cambió de sentido. En 1794, la corona española autorizó el libre comercio de mercaderías europeas entre los puertos de Chile, El Callao, Guayaquil y el Pacífico mexicano. ${ }^{24}$

23 Humboldt, Ensayo político, p. 250.

24 AGN, Instituciones coloniales, "Real Orden que permite la extracción e introducción de frutos, mercaderías y efectos de Europa entre este reino y el del Perú por los puertos del Sur”, abril de 1795, Bandos, vol. 18, exp. 10, fs. 44; también AGN, Bandos, vol. 20, exp. 87, fs. 191; AGN, Instituciones coloniales, Real Hacienda, vol. 130, exp. 9, 1800, f. 1. 
Disponemos de algunas evidencias sobre la llegada de embarcaciones del Perú a Acapulco y a otros puertos menores del Pacífico mexicano abasteciendo de géneros locales y manufactura europea. Por ejemplo, en 1802, el paquebot Mart ingresaba efectos europeos del Perú al puerto de Acapulco sin pagar derechos. ${ }^{25}$ En 1806, Juan de Antepara, vecino y comerciante de la Ciudad de México, solicitaba la devolución de la alcabala que se le había exigido de la primera venta de "efectos y frutos de Europa, de Guatemala, Santa Fe y Perú recibidos por los puertos del mar del Sur". ${ }^{26}$ Hacia 1818, según el gobernador de Nueva California, se presentó por sus costas la fragata Hermosa Mexicana, propiedad del comercio de Lima, al mando del capitán Gaspar Yllas, con textiles de algodón inglés, procedente del Callao. ${ }^{27}$ Los casos relatados muestran que el Pacífico mexicano estaba abandonando aquella función de reexpedir bienes extranjeros por el Mar del Sur. Ahora realizaba el proceso inverso, importando hacia los mercados regionales del occidente mexicano manufactura europea desde tierras sudamericanas, por medio de las embarcaciones peruanas o de origen europeo que previamente surcaban el Cabo de Hornos.

Respecto a la circulación de mercaderías asiáticas, su libertad para conducirlas libremente desde Acapulco hacia

${ }^{25}$ AGN, Instituciones coloniales, Reales Cédulas originales, vol. 183, exp. 1 , enero de 1802, f. 4.

${ }^{26}$ A GN, Instituciones coloniales, Indiferente virreinal, c. 2292, exp. 20, 1806, f. 18.

${ }_{27}$ A GN, Instituciones coloniales, Indiferente virreinal, c. 3915, exp. 33, 1818, f. 3. 
Guatemala y el Perú se efectivizará recién en $1803 .{ }^{28}$ No es casual que la autorización llegara en pleno contexto de políticas de libre comercio. Para entonces, una multiplicidad de flujos desde el Atlántico y desde el Pacífico movilizaban bienes y textiles asiáticos hacia Hispanoamérica. En este contexto, la libertad que se le concedió al galeón de Manila no representó un peligro para España. Desde años previos, buques particulares españoles o de la propia Compañía Real de Filipinas, fundada en 1785, erosionaban el exclusivismo comercial del galeón de Manila. Lo cierto es que el contrabando de telas asiáticas al Perú continuará durante la segunda mitad del siglo xviII, pero su ingreso se realizará, como tendremos ocasión de mostrar en páginas posteriores, en el marco de otras lógicas del comercio mundial e imperial.

De tal manera, el Pacífico de las últimas décadas del siglo XVIII no podría definirse como un lago indiano, una identidad atribuible para el periodo comprendido entre 1580 y 1740. El poder detentado por las corporaciones consulares de la Ciudad de México y de Lima se encontraba seriamente cuestionado con la incursión de nuevas rutas, mercados y la presencia de los comerciantes peninsulares en el juego del trato oriental. La decadencia del galeón de Manila fue una expresión directa de la erosión que sufrió el Consulado novohispano, particularmente en su facultad monopólica de importación de bienes y salidas de plata por el eje transpacífico. El concepto Spanish Lake, término que gran parte de la historiografía adoptó para el Pacífico, parece ser, de ahora en más, la identidad más adecuada. Las compañías comerciales

28 El 13 de julio de ese año se emite dicha legislación. VALDÉs LAKOwsKY, De las minas al mar, pp. 241-242. 
españolas incursionarán en las aguas del Pacífico con capitales, agentes y derroteros alternativos, cuestionando el control de antaño de los más reconocidos mercaderes indianos sobre el galeón asiático y el comercio entre México y Perú por el Mar del Sur. El monopolio de los novohispanos en el circuito transpacífico también será discutido desde Filipinas, con la creación de un consulado propio en 1769. La flamante corporación aspiró a proteger los intereses comerciales particulares de los insulares en detrimento de los novohispanos. ${ }^{29} \mathrm{El}$ Pacífico adquirirá una nueva “estampa”, una suerte de refundación española del Pacífico. ${ }^{30}$ Pero el Spanish Lake tendrá una vida breve, limitada al periodo entre 1750 y 1790 . Hacia fines del siglo, los ingleses, y en menor medida los angloamericanos dominaron los intercambios, bautizando al área como un Pacífico extranjero.

En efecto, a partir de los últimos años del siglo XVIII, el Pacífico cobró una nueva vida. La expansión comercial británica y estadounidense proveniente del Atlántico no sólo rompió con ese lago indiano relativamente independiente y vinculado al modelo comercial con centro en la Ciudad de México y al espacio asiático, sino que también erosionó esa existencia hispánica que los Borbones lograron imprimirle durante las últimas décadas de la centuria. De ser un lago indiano, el Pacífico pasó a tener una breve vida como lago español y, luego de 1790, se asemejó a un Pacífico extranjero, mayormente inglés. La manifestación más clara de la extranjerización se ilustró, para el caso

${ }_{29}$ AGI, "Remisión del Reglamento a la ciudad y comercio de Manila", 1769, Filipinas, 36, leg. 18, fs. 95-96.

30 Vives Anzacot, “El Pacífico español”, pp. 245-257. 
del Pacífico mexicano con la compañía comercial británica Barron \& Forbes, que comenzó a funcionar en Tepic a partir del segundo cuarto del siglo xix. ${ }^{31}$ Gran Bretaña aprovechó la fragmentación económica y el conflicto social y político generado por los procesos de las independencias nacionales para su expansión imperialista por el Pacífico. Claro está que la intromisión inglesa fue posible por la voluntad política y económica de las elites locales y regionales que habían sido marginadas en el modelo comercial colonial precedente. Lo cierto es que, ya fuera ibérico o inglés, el Pacífico fue desde 1750 un espacio marítimo condicionado por el devenir de la economía noratlántica europea. El gran fenómeno mundial podría sintetizarse con una breve frase: antes de 1750 el Atlántico se encontraba pacificado; a partir de esa fecha el Pacífico sufrió una atlantización. La hipótesis propuesta alcanzará mayor claridad con los restantes factores que provocaron la desaparición del modelo que colocó a México y su capital en uno de los puntos de confluencia de la economía global de la temprana modernidad.

\section{LA RUTA ENTRE EUROPA Y EL PACÍFICO HISPANOAMERICANO} POR EL CABO DE HORNOS

En 1711 el virrey novohispano, Duque de Linares, recomendó la institucionalización del tejido mercantil que

${ }^{31}$ En 1830 se fundó la empresa Barron \& Forbes en Tepic. Su influencia no sólo se notó en el Pacífico, sino que alcanzó una trascendencia en la política económica internacional del flamante Estado mexicano. Barron, presidente y fundador de la Compañía, alcanzó el cargo de cónsul británico en México durante su actividad empresarial. Para mayor detalle sobre el éxito de los extranjeros por el Pacífico mexicano véase MaYo, "Imperialismo de libre comercio”, pp. 673-696 y Contreras VALDEZ, Nayarit, pp. 77-79. 
ubicaba a la capital novohispana como el centro de las relaciones del imperio. Según Linares era necesario legalizarlo porque lograría combatir y eliminar el tráfico de los franceses, que por entonces movilizaban bienes europeos y plata peruana entre Saint Malo, Buenos Aires, Cabo de Hornos, Perú, México y China. ${ }^{32}$ El tráfico ilícito galo por el estrecho austral exigía la aceptación de la centralidad novohispana, porque permitiría que las capitales de Santiago, Lima y Quito se surtieran de bienes ultramarinos legalmente desde México. Sólo así la plata andina circularía por derroteros controlados por el Estado español, eliminando el escape de metálico andino que realizaban los franceses a través del Cabo de Hornos.

Lo notable es que hacia 1740, casi 30 años después de aquella recomendación del virrey, la ruta del Cabo de Hornos se convirtió en la vía oficial española de paso interoceánico para conectar a España y Europa con el Pacífico sudamericano. ${ }^{33}$ La desaparición de los galeones, con sus respectivas ferias de Portobelo, permitió que el navío de registro se posicionara como el medio de transporte dominante de un sistema comercial ahora más "libre". Desde 1740, los barcos particulares contarán con autorización para cruzar el Cabo de Hornos y vender las mercaderías extranjeras traídas desde Europa en los puertos de Chile, Perú y Ecuador. La crisis y el definitivo colapso de la feria de Portobelo producida por la guerra con Inglaterra motivaron (u obligaron) a España a diseñar una vía mercantil alternativa para el intercambio con el virreinato del Perú.

32 Bonialian, El Pacífico, pp. 228-258.

33 Lamikiz, Trade and Trust, pp. 81-83. 
Cuando el poder español institucionalizó el paso por el Cabo de Hornos para alcanzar los mercados del Pacífico sudamericano era consciente de que, a fin de cuentas, estaba aplicando un duro golpe a la centralidad mercantil novohispana. La percepción geopolítica de la Monarquía sobre los circuitos imperiales modificó rotundamente su sentido. Desde finales del siglo xvi, el paso del Cabo de Hornos fue definido como una vía de contrabando de los enemigos europeos, que requería combate y clausura para garantizar la Carrera de Indias. Pero a partir de 1750 se le concibió como el principal derrotero para el avance hispánico sobre el modelo comercial de largo alcance que ubicaba a México y su Pacífico como una suerte de "metrópoli” mercantil. La apertura oficial del estrecho magallánico trastocó la estructura comercial del imperio hispánico y aun del globo. El arribo de navíos de registros españoles desde 1750 y, cuatro décadas más tarde, de balleneros ingleses y angloamericanos con enormes cargas de mercadería a los puertos de Valparaíso, El Callao, Guayaquil, Panamá y del Pacífico mexicano, provocó la parálisis de una de las "arterias” del corazón del tejido mercantil preexistente. El abastecimiento europeo por la ruta del Cabo cortó el circuito ilegal de mercancía asiática y europea que barcos peruanos realizaban desde México hacia sus puertos. Una contracción que, al mismo tiempo, no hizo más que eliminar el papel de la Ciudad de México como punto redistribuidor central de bienes en una gran porción del mercado sudamericano. El cierre del frente consumidor sudamericano repercutió negativamente en la economía de México. Esto explicaría la decadencia del tráfico del galeón de Manila y el descenso de los volúmenes de carga operados en los años finales de vida de la flota de Veracruz. 
La apertura española de la ruta del Cabo de Hornos dinamizó el comercio de España con el espacio peruano y rioplatense. ${ }^{34}$ Durante la segunda mitad del siglo el espacio hispano sudamericano equiparó la intensidad de la circulación de navíos y comercio que presentó el flujo comercial entre España y México. ${ }^{35}$ Se podría suponer que, en estos titánicos derroteros, las naves procedentes del Atlántico europeo internaron sus mercaderías en Buenos Aires y luego, por vías terrestres, llegaron a los mercados del Pacífico chileno. Pero los estudios de Carmagnani dan cuenta de que el eje marítimo Buenos Aries-Cabo de Hornos-Valparaíso adquirió mayor relevancia y dinamismo que el circuito terrestre Buenos Aires-Mendoza-Santiago. La preferencia se prolongó en las primeras décadas del siglo XIx. Entre 1810 y 1819, las importaciones de bienes europeos representaron en el comercio de Santiago 33.2\% del total, de los cuales $32.7 \%$ correspondían a la vía marítima y sólo $0.5 \%$ a las internaciones procedentes de Buenos Aires. ${ }^{36}$ Evidentemente, las luchas por la independencia, la falta de mantenimiento

${ }^{34}$ Lamikiz, Trade and Trust, pp. 81-113.

35 Si antes de 1750 el virreinato novohispano concentró la mayoría del tráfico ultramarino, en el transcurso de la segunda mitad del siglo la circulación de navíos por Sudamérica llega a equiparar en números y tonelajes de barcos a los registrados por México. Se dispone de los siguientes cálculos para el periodo comprendido entre 1740 y 1778: considerando sólo Nueva España y el Perú vemos que el porcentaje de tonelaje fue de 39\% hacia Nueva España y 31.6\% hacia Tierra Firme. En cantidad de navíos: $33.8 \%$ hacia y desde Nueva España y $35.2 \%$ para Tierra Firme. Datos arrojados por García Baquero, Cádiz y el Atlántico, p. 268.

${ }^{36}$ Carmagnani, Los mecanismos, pp. 87-88. Esta primacía no desconoce el efecto de atracción de bienes extranjeros por el mercado consumidor de Buenos Aires y su binterland. 
y las dificultades de los circuitos terrestres interregionales explican esta selección.

La reorientación a través del Cabo de Hornos ofreció mayores oportunidades de crecimiento a puertos y mercados emergentes del Pacífico. Hasta la primera mitad del siglo xviII, la vida comercial de los puertos de Valparaíso, Paita y Guayaquil exclusivamente dependía de los ritmos dictados por los ejes Ciudad de México-Acapulco-Callao o, el del Atlántico, Portobelo-Callao. El caso de Santiago de Chile y su puerto de Valparaíso requiere una particular atención. Según los trabajos realizados por Cristina Mazzeo, el comercio de Chile continuó sujeto y dependiente hasta la primera década del siglo XIX a la vida mercantil del Perú y de los comerciantes limeños. Recién hacia 1820, con la instalación efectiva de casas comerciales británicas en Chile, Valparaíso logró romper el tutelaje peruano. ${ }^{37}$ Una visión diferente la ofrecen los estudios de Carmagnani y Cavieres, quienes sugieren que desde la segunda mitad del siglo XviII, Chile comenzó a romper con la tradicional dependencia del comercio peruano y a dinamizar la relación directa con España y con el puerto de Buenos Aires. ${ }^{38}$ Tanta importancia habría alcanzado el polo chileno que, según estos estudios, se convirtió en el puerto dominante del Pacífico sur en el transcurso de la segunda mitad de aquella centuria, posición que prevalecerá durante la primera mitad del siglo xix. Por su parte, la institucionalización de la vía por el Cabo de Hornos afectó, además, la función que desempeñó Panamá

37 Mazzeo, "El circuito comercial”, pp. 421-453.

38 Carmagnani, Los mecanismos; Cavieres, "Comercio, diversificación”, pp. 93-110. 
en el comercio colonial e interregional. Hacia 1700 Panamá representó un considerable $6 \%$ del comercio interregional realizado por todo el Pacífico. Hacia finales de siglo sólo alcanzó $1 \% .{ }^{39}$ Es más, en la primera mitad del siglo XIX, el mercado de Chile se abastecía de textiles británicos por la vía del Cabo de Hornos, muy raramente por el istmo de Panamá, vía esta última que era utilizada sólo para la circulación de pasajeros y de inteligencia. ${ }^{40}$

Ahora bien, a pesar de las distancias espaciales y de las realidades históricas que nos parecen ajenas, la apertura del Cabo de Hornos generó profundas consecuencias en la economía de México. La ruta austral que vinculó Europa, Buenos Aires, el Pacífico hispanoamericano y China no hizo más que desarticular el tejido entre Acapulco, la Ciudad de México, Veracruz, España, China y el Perú, puntos que habían operado como las "columnas" del modelo precedente. ${ }^{41}$ Si antes era la Ciudad de México - por medio de sus grandes comerciantes - la llave que abrió la puerta para la comunicación entre el Atlántico y el Pacífico, desde 1750 fue la ruta por el cabo austral el punto interoceánico geoestratégico que permitió el avance europeo no sólo hacia

39 Su resurgimiento se dará recién en 1855, con la construcción de la vía férrea que conectará ambas orillas de su estrecho territorio. LEón, “Comercio por el Mar del Sur”, pp. 318-329.

40 Llorca-Jaña, The British Textile, pp. 209-210.

41 En la búsqueda por identificar las razones de la emergencia de los mercados del Pacífico sudamericano, la historiografía atendió con mayor énfasis la relación de contracción y competencia entre el eje comercial Cádiz-Portobelo-Lima y la ruta del Cabo de Hornos. Véase, por ejemplo, Villalobos, Comercio y contrabando, pp. 29-30. Aquí enfatizamos los efectos causados por el derrotero austral sobre el brazo comercial desde el puerto de Acapulco hacia El Callao. 
los mercados occidentales de Hispanoamérica sino también hacia China. La transformación no fue lo suficientemente valorada por los estudios históricos ocupados en la longue durée de la historia económica mexicana. Se encuentra prácticamente omitida por quienes rastrean las razones de su reposicionamiento geopolítico y económico en tiempos del reformismo borbónico hasta las políticas liberales de la emergente nación. Estaríamos en presencia de un momento de inflexión en la historia económica de México: se desvaneció el eje terrestre Veracruz-Ciudad de México-Acapulco como punto de confluencia americana entre las economías de China y de Europa, para reubicarse, en un contexto de fragmentación y regionalización económica, en una simple "periferia" del capitalismo europeo, una suerte de enclave económico del mundo noratlántico en plena expansión.

Veamos el problema con algunas cifras. En 1748, apenas inaugurada la ruta austral, aportaron al puerto de El Callao unos 18 navíos españoles. En 1761, la cifra aumentó a 56. En 1786, sólo al puerto limeño llegaron 16 navíos de registro cruzando el cabo austral; cuando sabemos que, por esos años, numerosos puntos costeros registran una intensa actividad. Para los años finales del siglo xviıI, el promedio de embarcaciones anuales que llegaron al puerto del Río de la Plata fue de 60, muchas de las cuales extendieron su travesía hacia el Pacífico por el Cabo de Hornos. ${ }^{42}$ "Entre los años 1778 a 1796 circulan de Cádiz a El Callao unos 153 barcos, y entre 1809 a 1820 unos 90 ". ${ }^{43}$ Entre 1785 y 1796, las exportaciones de mercaderías desde Cádiz al Río de La Plata y a la

\footnotetext{
${ }^{42}$ Villalobos, Comercio y Contrabando, pp. 40-56.

43 Parrón Salas, p. 320.
} 
costa del Pacífico sudamericano (Valparaíso, Arica, Callao y Guayaquil) contabilizaban 33\% del total, ubicándose en la segunda área mercantil de importancia detrás de México y el Caribe. ${ }^{44}$ En fin, los navíos de registro llevaron enormes cantidades de plata peruana hacia Cádiz. A cambio importaron por los puertos del Pacífico sudamericano telas crudas o terminadas, hierro, acero, artículos de ferretería, cera, papel, libros, medicamentos, vidrio y especies del Oriente. Hacia mitad del siglo, la ropa (término genérico utilizado en las fuentes) de origen europeo y del Oriente representaba $65 \%$ de la canasta importadora. ${ }^{45}$

Dicho esto, valdría preguntarse cuántos de estos navíos españoles que operaron en la costa del Pacífico sudamericano extendieron su radio de acción hacia México, por Huatulco, Acapulco, San Blas o Mazatlán. Es posible que un porcentaje bajo, más considerando que por el Pacífico novohispano se exploraban nuevas líneas de comercio de cabotaje y de expedición hacia el Golfo de California. Pero lo fundamental no sería precisar el número de navíos, sino reconocer que la incesante corriente de barcos españoles y europeos que navegaron a través del Cabo de Hornos le arrebató al eje Ciudad de México-Acapulco la función de espacio abastecedor de bienes extranjeros sobre el mercado del Perú.

Ahora bien, las independencias políticas hispanoamericanas no parecen representar un fenómeno de cambio en el escenario mercantil y geopolítico aquí tratado. Más bien, profundizaron el fenómeno que se venía registrando desde

\footnotetext{
44 Fisher, El comercio, pp. 22-23.

45 Lamikiz, Trade and Trust, pp. 83-84.
} 
las décadas previas. Si en la segunda mitad del siglo xviıI fueron los navíos de registro español los que dominaron la ruta del Cabo de Hornos, a partir de los años finales de la centuria y gracias a la autorización para el "comercio de neutrales” (1797), el tráfico de embarcaciones inglesas, estadounidenses, y en menor medida de otras naciones europeas, intensificó la circulación por el eje austral. ${ }^{46}$ Gran Bretaña fue la principal potencia marítima comercial por estos tiempos, pero no debería desconocerse la competencia que le suscitaron los navíos de compañías estadounidenses, que fueron la segunda flota mercante a nivel global. Lo cierto es que, ya desde 1790, con el tratado de paz angloespañol de San Lorenzo, la corona hispánica cedió el paso por el Cabo de Hornos y las aguas del Pacífico hispanoamericano a balleneros ingleses para la explotación del aceite, pieles de nutrias y focas. ${ }^{47}$ Desde 1788 hasta 1809 navegaron 165 buques ingleses y estadounidenses entre los puertos y mercados del espacio comprendido entre Valparaíso y California. ${ }^{48}$ Serán los ingleses y los estadounidenses quienes se apropiarán de la ruta por el eje austral, extendiendo de

${ }^{46}$ De hecho, se señala que para el Río de la Plata, Chile y Perú la actividad marítima mercantil no sólo se mantuvo, sino que se intensificó. Villalobos, Comercio y contrabando, pp. 90-96.

47 Ramiro Flores afirma que el tratado de 1790 representó la "desnacionalización del comercio peruano", en el sentido de que al amparo de la autorización que benefició a los ingleses arribaron también naves estadounidenses y de otras naciones europeas al Pacífico español. La interpretación es compatible con nuestra idea de un "Pacífico extranjero". FLores, "Los balleneros", pp. 63-64.

48 Pereira Salas, Los primeros contactos, pp. 315-353. Villalobos nos ofrece una cifra más elevada. Durante ese periodo habrían pasado por el Cabo de Hornos hacia el Pacífico 257 barcos (sólo estadounidenses). Villalobos, Comercio y contrabando, p. 94. 
manera sistemática los intercambios comerciales desde Chile, pasando por California, hasta llegar a China.

Ya sea para el intercambio de plata o por cuestiones geoestratégicas, muchos de los navíos ingleses y estadounidenses arribaron a algún puerto del Pacífico mexicano. Jorge León contabilizó unos 80 barcos balleneros y cazadores de pieles por los puertos de Chile, Perú y México hacia 1800 , participando en un activo contrabando que respondió a la gran demanda de bienes europeos. ${ }^{49}$ Cargaban en sus puertos de origen manufacturas, particularmente textiles de algodón inglés. Algunas de ellas recalaron en Boston, Nueva York y Baltimore luego de cruzar el Atlántico. Posteriormente transitaron hacia el sur por el Atlántico hispanoamericano haciendo intercambios en el Caribe, hasta llegar a Buenos Aires. Cruzaron el Cabo de Hornos y despacharon bienes asiáticos y europeos en los puertos de Chile, del Perú, de Panamá y en los del Pacífico mexicano. En estos derroteros adquirieron productos locales para realizar el comercio de cabotaje por toda la costa occidental del continente. Prolongaron su comercio en Asia para adquirir algodones y especies de la India, sedas y porcelanas de China. En su retorno esos mismos productos fueron intercambiados por pieles de nutria y focas, ya sea para venderlos en las costas norteñas de México y de Estados Unidos o para destinarlos al mercado europeo donde gozaban de estima y elevados precios (véase el mapa 2).

Entre 1817 y 1818 en las costas peruanas había más de 100 balleneros estadounidenses que habrían alcanzado el

${ }^{49}$ León, “Comercio por el Mar del Sur”, p. 326. 
occidente mexicano. ${ }^{50}$ Hacia 1830 , el guano del Perú y de Bolivia se integró en esta compleja y rica red mercantil, aportándole a la ruta austral un renovado impulso para su desarrollo. ${ }^{51}$ El conjunto de estos intercambios generó una importante movilización de plata mexicana hacia Estados Unidos, China y Europa, logrando romper aquellos conductos metalíferos con impronta monopólica que estaban en poder de las tradicionales corporaciones consulares y que fueron vitales para el armado del modelo semiinformal con centro en la Ciudad de México. ${ }^{52}$

De ahí, nuestra comprensión sobre la evolución de la política económica que se aplicó sobre el gran espacio del Pacífico hispanoamericano durante las primeras décadas del siglo xIx. La voluntad de un tráfico plenamente libre entre México y Perú ya se había dictado en una real cédula expedida por Carlos IV el 18 de septiembre de 1803, disponiendo el "fomento de la navegación y el comercio entre los reinos del Perú, Nueva España, Granada y Guatemala y los puertos del mar del Sur". ${ }^{53}$ Tres décadas después, hacia 1833, el Gobierno mexicano firmaba el "tratado de amistad, comercio y navegación entre México y la República del Perú". 54 A pesar de las profundas transformaciones

\footnotetext{
50 Flores, “Los balleneros", p. 85.

51 Bonilla, “La coyuntura”, pp. 305-331.

52 Seguramente, la historia de la circulación de metálico ameritaría un trabajo independiente y profundo, que supera el propósito del presente ensayo.

53 AGN, Instituciones coloniales, Gobierno Virreinal, Impresos oficiales, contenedor 22, vol. 54, exp. 41, 18 de septiembre de 1803, fs. 212-215.

54 AGN, Instituciones Gubernamentales, Gobernación (127-128), Circular del Ministerio de Relaciones Exteriores, Gobernación y Policía, vol. 160, exp. 18, s/n de f.
} 
políticas, había un patrón común de orientación tendiente al libre comercio y la injerencia europea entre las medidas dictadas en el periodo colonial e independiente. En este contexto, en 1840 llegaron en más de 32 naves europeas y estadounidenses a San Blas procedentes del Pacífico sudamericano. La mayoría de ellas cruzaron el Cabo de Hornos luego de haber partido desde el Atlántico europeo o estadounidense. ${ }^{55}$ Sabemos también que en 1839 recalaron al menos dos barcos procedentes de Hamburgo al puerto de Mazatlán, luego de cruzar el Cabo de Hornos, una travesía que duró entre cuatro y seis meses. ${ }^{56}$ Es muy posible que estos cálculos en el movimiento de barcos fuera un piso mínimo, más considerando que, según las estadísticas de Jorge León, las travesías, que hasta la década de 1830 no superaban un promedio de 50 al año, a partir de 1840 se cuadruplicaron. ${ }^{57}$

Cierto es que estamos en presencia de un Pacífico fragmentado y diversificado, resultado de las guerras de emancipación. Pero los pocos estudios dedicados a la historia mercantil de las primeras décadas del siglo XIX adoptan una perspectiva Estado-nación, concentrando la atención en el horizonte del comercio de cabotaje o en los movimientos expedicionarios hacia el norte californiano. En verdad, el Pacífico mexicano continuó siendo un área permeable y móvil, con fuertes influencias por los cambios que se

\footnotetext{
${ }^{55}$ Meyer, Breve historia de Nayarit.

${ }^{56}$ Dane, "Primeras relaciones", p. 86. Según Llorca-Jaña el tiempo que duraba el viaje desde Inglaterra hasta el Pacífico sudamericano era de 120 a 180 días. Recién en la segunda mitad del siglo XIx, se logró reducir el tiempo de derrotero gracias a las mejoras en las técnicas náuticas y la utilización de los barcos de vapor. LlorCa-Jaña, The British Textile, p. 213. ${ }^{57}$ León, "Comercio por el Mar del Sur”, p. 335.
} 
vivieron no sólo en las costas de Sudamérica sino también del Atlántico. Tanto el Pacífico septentrional como el meridional fueron, en definitiva, piezas de una economía global más unificada: si antes de 1750 los mercados occidentales de Hispanoamérica se veían fuertemente orientados al polo asiático (uno de los principales centros de la globalización policéntrica), desde finales del siglo xviri la unidad naval del Pacífico se vio apuntalada por las economías europeas $\mathrm{y}$ estadounidense.

Finalmente, como telón de fondo de esta historia comercial de larga duración, debemos advertir que el aumento del tráfico por el Pacífico mexicano y estadounidense durante la segunda mitad del siglo xIX se debió más a la apertura de la vía férrea por Panamá que al paso por el Cabo de Hornos. Desde entonces, la circulación de navíos europeos por el eje austral pierde sistematicidad. La inauguración del ferrocarril de Panamá (1855) provocó que la movilidad de barcos y hombres por la ruta transcontinental del Cabo de Hornos iniciara su ciclo secular de descenso. ${ }^{58} \mathrm{Si}$ bien el derrotero permaneció en operación, por costos de comercialización y tiempo de navegación, Panamá desplazó al Cabo de Hornos como el principal paso transoceánico del continente en la interacción entre las economías del Atlántico y del Pacífico. A partir de 1840, el descubrimiento y la explotación del oro de las minas de California configurará un nuevo tejido de redes comerciales internacionales, problemática que supera el análisis de nuestro ensayo.

${ }^{58}$ Un recorrido de $77 \mathrm{~km}$ de rieles unía por esos tiempos la ciudad de Colón con la propia ciudad de Panamá. Busto Ibarra, "El espacio del Pacífico”, pp. 125-129. 


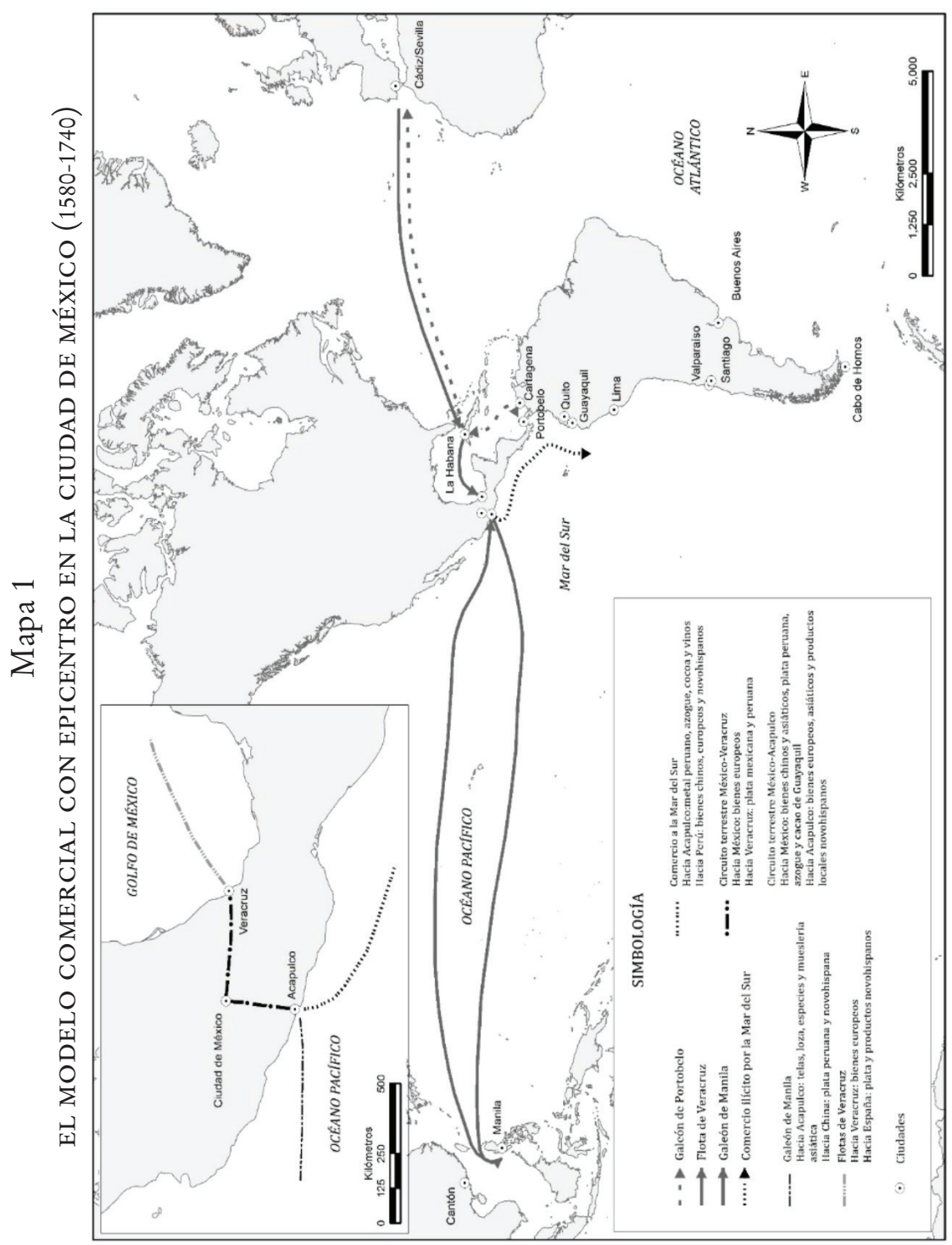




\section{Mapa 2}

EL MODELO COMERCIAL EUROPEO (1740-1840)

CABO DE HORNOS COMO VÍA INTEROCEÁNICA

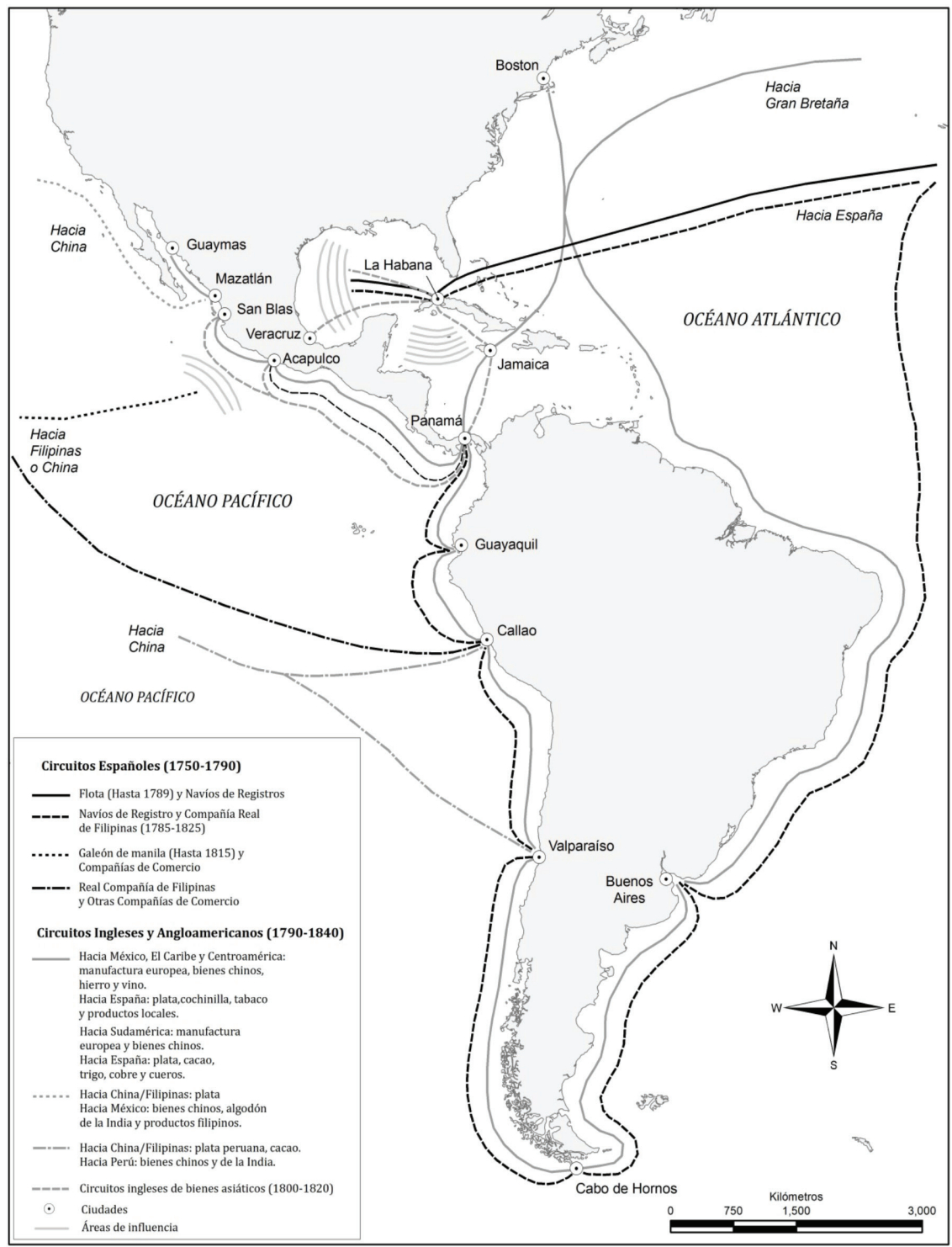


LA REVOLUCIÓN ATLÁNTICA DEL COMERCIO Y CONSUMO:

BIENES ASIÁTICOS, SUS IMITACIONES EUROPEAS

Y LOS TEJIDOS DE ALGODÓN INGLESES

EN LOS MERCADOS HISPANOAMERICANOS

En su momento señalamos que el funcionamiento del modelo semiinformal con epicentro en la Ciudad de México se sujetó al principio de complementariedad de bienes entre el eje transpacífico y el trasatlántico, desde 1580 hasta 1740 . ¿A qué nos referíamos con este principio? Relativizamos la premisa historiográfica que apunta a una permanente rivalidad entre el galeón de Manila (comerciantes novohispanos) y la flota de Veracruz (cargadores peninsulares) que presupone una competencia entre los dos ejes para lograr imponer sus productos en el mercado de élite de Nueva España. ${ }^{59}$ Sin desacreditar el foco de conflicto y la competencia suscitados en torno a una reducida clase social consumidora del virreinato, sugeríamos que la complementariedad entre ambos flujos resultó más relevante porque permitió el desarrollo en el marco del comercio exterior novohispano de intercambios estructuralmente armónicos. La complementariedad se reveló como más pujante que la competencia, al detectar que la mayor parte del cargamento que ingresaba por Acapulco, en particular el textil bruto o semielaborado, se destinó a un consumo social ampliado y popular. Por el contrario, los productos europeos que vinieron a México en las flotas de Veracruz, con mayor costo, terminados, de calidad y exquisitos, se destinaron a la élite, a una parte minúscula de la población novohispana.

${ }^{59}$ Bonialian, China en la América, pp. 27-82. 
Una de las evidencias más contundentes de cómo operó la complementariedad se descubría al evaluar la composición de la carga de los navíos peruanos que arribaron a sus costas procedentes de los puertos occidentales de México. La carga se dividía en partes prácticamente exactas de géneros de China y de efectos de Castilla (o europeos). Una considerable porción de los cargamentos asiáticos respondía a la demanda popular o para agregarles un valor agregado, "industrial”, ya sea en los centros manufactureros novohispanos o, en menor grado, en los obrajes del Perú. Los segundos, más elaborados y terminados, fueron los solicitados por los sectores privilegiados de los residentes españoles ${ }^{60}$ Las partidas de tela semielaborada, de tejidos de algodón y de sedas producidos en Filipinas, China o, más tarde, en la India, constituyeron, junto con las vajillas y los textiles de producción local americanos (los llamados efectos de la tierra), los artículos más solicitados por un amplio sector social.

Ahora bien, la complementariedad, pilar fundamental para el desarrollo del tejido mercantil que ubicó a la Ciudad de México como cabecera, se desplomó durante la segunda mitad del siglo xviII. Mucho tuvo que ver en eso el proceso de atlantización del comercio y consumo de bienes extranjeros en Hispanoamérica, que se inició, para el caso español, con el reformismo borbónico. La interpretación sobre la "revolución del comercio" no debería limitarse a las transformaciones de la cultura económica y de los hábitos de consumo en la sociedad europea ${ }^{61}$ El término alcanzaría su más amplia manifestación cuando se considera la apertura

60 Bonialian, China en la América, pp. 27-82 y 84-95.

61 Carmagnani, Las islas de lujo. 
de nuevas rutas y puertos por la Monarquía española y, en segundo lugar, con la explosión de la importación y consumo de productos europeos, asiáticos o sus imitaciones destinados al mercado hispanoamericano que llegaron desde Europa.

En el apartado anterior dimos cuenta de que, durante las décadas finales del siglo XviII, la economía atlántica europea inició una efectiva intervención sobre el área del Pacífico. Esta presencia europea (primero por los españoles, luego por los ingleses y angloamericanos) fue, al mismo tiempo, la expresión de dos hechos trascendentes y simultáneos: 1) la expansión global de la economía europea sobre mercados que, hasta entonces, no contaban con su efectiva intervención y explotación; 2) los inicios del retraimiento de China en la economía global y, en particular, en Hispanoamérica; un fenómeno que se profundizará durante la segunda mitad del siglo xIx. Se parte del calificativo de una economía global policéntrica vigente desde el siglo xvi hasta mediados del xvini, en la que China y la India fueron los principales productores. En ese contexto, el Pacífico hispanoamericano, en tanto espacio proveedor de plata e importador de bienes asiáticos, tuvo mayor vinculación con la economía del mundo de Oriente en relación con la economía mundo europea occidental. Ahora bien, la economía mundial se transformó abruptamente en las décadas finales del siglo xviII, siendo Inglaterra el mayor centro de producción de bienes industriales orientados a los mercados globales. ${ }^{62}$ De ahí podemos

${ }^{62}$ Luego de la globalización policéntrica, que tendría su fin hacia finales del siglo xviII, se inició una era global de una economía industrial especializada, siendo su motor Inglaterra. Findlay y O'Rourke, Power and Plenty. Sobre el ascenso y retraimiento de China en el fenómeno global de la economía moderna: VRies, State, Economy. Sobre cuestiones 
comprender el proceso de apropiación del Pacífico por parte de Europa occidental, que se hará más profundo durante las primeras décadas del siglo XIX, con el efecto concreto de la revolución industrial inglesa. Claro está que la "atlantización" resulta ser un episodio de magnitudes insospechadas para su análisis. Aquí nos interesa señalar tres aspectos relevantes de la "atlantización" que explicarían la razón del desmoronamiento del modelo comercial precedente, la contracción de la circulación de los productos asiáticos en los mercados del globo y el dominio atlántico occidental sobre el Pacífico en el comercio imperial y global.

a) La Mercadería asiática y su circulación por el Atlántico. Considerables porciones de telas brutas y textiles orientales que antes de 1750 se movilizaban exclusivamente por el Pacífico con el galeón de Manila se vieron desplazadas hacia el Atlántico a raíz del contrabando inglés y holandés, de los navíos de registro asociados al "libre comercio" y a la flota de Veracruz (en los pocos años de vida que le quedaban hasta 1789). Como mencionamos, la crisis del galeón de Manila tendría parte de su explicación en la aparición y competencia de las compañías españolas que estaban operando en el Pacífico. Sin embargo, la "atlantización" del trato y el consumo de productos asiáticos en el continente americano parece haber sido su golpe de gracia. A partir de la segunda mitad de siglo xviII, gran parte de la contratación asiática se encontraba monitoreada por las casas comerciales europeas. En los informes y memoriales de la época se puede encontrar la denuncia de la negociación que establecieron

relativas a la historia global y la función que cumple el Pacífico en ella, véase Flynn y GiráldeZ, “Los orígenes”, pp. 29-76. 
las casas comerciales españolas y europeas para movilizar sedas, algodones de la India, de China y porcelana asiática desde el Atlántico rumbo a los mercados hispanoamericanos. Los géneros asiáticos, todavía ilegales para su comercialización en América hasta los primeros años del siglo XIX, se veían etiquetados como producción europea, con vistas a evadir cualquier intento de sanción o confiscación. ${ }^{63}$ Abundantes testimonios y fundamentalmente las estadísticas comerciales rescatadas por Lerdo de Tejada sobre la aduana de Veracruz muestran que desde 1790 y durante las primeras décadas del siglo XIX se importaron a México grandes cantidades de algodón "de la China y de la India”. ${ }^{64}$

Hacia 1811, el editor de la Gaceta de México, Juan López Cancelada, ponía al descubierto la movilización de bienes asiáticos. Lamentaba la falta de una política proteccionista en México que protegiera el desarrollo de la industria textil local. El librecambismo económico subyacente con el comercio británico era la pauta de funcionamiento para México. ${ }^{65}$ Cancelada confesaba que las políticas económicas para regular las importaciones británicas sólo eran posibles en coyunturas excepcionales de guerra, con el bloqueo

${ }^{63}$ UlloA, Restablecimiento, p. 343; Abbad y Lasierra, AGI, "Comercio de Filipinas”, en Estado, leg. 47, exp. 10, fs. 26-27.

${ }^{64} \mathrm{AGN}$, Instituciones coloniales, Indiferente virreinal, c. 6154, exp. 10, fecha 1791, f. 218. El proceso también puede rastrearse en el pago de las alcabalas. Véase al respecto AGN, Instituciones coloniales, Indiferente virreinal, c. 6527, exp. 22, fecha: 1795, f. 24. Para las primeras décadas del siglo XIX véase Lerdo de TeJAdA, Comercio (documentos).

${ }^{65}$ El debate entre industria y libre comercio en México fue un fenómeno que ocurrió antes de la independencia, aunque las discusiones tomaron mayor relieve hacia 1830 . Véase al respecto TuTINo, “El debate”, pp. 1119-1192. 
de los circuitos trasatlánticos. Pero proseguía afirmando que "hecha la paz con la Gran Bretaña, volvieron de nuevo las introducciones de la Europa y por los mismos mares muchas del Asia". ${ }^{66}$

En este escenario, se ha pasado por alto un hecho trascendente: en las primeras dos décadas del siglo XIX, los comerciantes ingleses asentados en Jamaica comercializaban de manera deliberada tejidos de algodón de la India y de China en los puertos atlánticos de Tampico y Veracruz o, vía Panamá, en puertos del Pacífico como Acapulco y San Blas (mapa 2) ${ }^{67}$ El comercio de los ingleses desde Panamá hacia San Blas ya no sólo venía a propinarle los últimos golpes al moribundo comercio del galeón de Manila, sino también a la Compañía Real Española de Filipinas, cuyas operaciones concluirían hacia 1820 ante la inviabilidad de operar en las emancipaciones iberoamericanas. Los comerciantes de la Ciudad de México protestaban que los tejidos de algodón de la India y de China tenían un efecto devastador sobre la estructura textil local. México no era un caso excepcional: la importación de productos asiáticos procedentes de Europa se reproducía por todas las plazas iberoamericanas, desde las islas del Caribe y La Habana ${ }^{68}$ hasta Buenos

66 López CANCElada, “Ruina de la Nueva España”, p. 110.
67 VAldÉs LaKowsKy, De las minas al mar, pp. 241-247.
68 En 1778, año del famoso decreto de "libre comercio", una autoridad
aduanera en La Habana señalaba que en "las embarcaciones del comercio
libre que vienen a este puerto de los de España se conducen muchas veces
géneros de China”. El funcionario le consulta al Consejo de Indias si son
"legítimos de introducción, aunque no conste su especial habilitación”. Si
se autoriza, "serán muchos los fraudes que irremediablemente se come-
terán contra la Real Hacienda, porque teniendo los reinos extranjeros
mucho comercio con los de China, introducirán sus géneros a la sombra 
Aires ${ }^{69}$ Es más, el trato comercial de géneros asiáticos hecho por comerciantes ingleses, franceses y estadounidenses proseguía hacia el Pacífico, luego de cruzar el derrotero del Cabo de Hornos y llegar a los puertos de Valparaíso ${ }^{70}$ y El Callao. ${ }^{71}$

b) Las imitaciones europeas de los bienes asiáticos. Aquella complementariedad mercantil entre los dos ejes oceánicos también se deshizo porque los propios bienes asiáticos comenzaron a reproducirse e imitarse en los centros manufactureros europeos. Al menos desde finales del siglo XviI Europa venía consumiendo bienes europeos que tenían diseños y estilos orientales. ${ }^{72}$ Con sólo repasar los inventarios de bienes familiares se confirma que las imitaciones europeas de bienes asiáticos resonaron masivamente en los mercados de Hispanoamérica casi un siglo después, durante la

de los que vienen a España, por el giro suyo, perjudicándose las fábricas del reino"; en AGI, "Expediente del comercio libre (1778-1779)", Indiferente, 2415, s/n de f.

${ }_{69}$ Bonialian, China en la América, pp. 119-181 y 196-246.

70 En 1771, el navío denominado Oriflama, de procedencia gaditana, navegó por el Cabo de Hornos hasta llegar a las costas chilenas del corregimiento de Maule. Cuando se inspeccionaron sus mercaderías, el funcionario notó que una gran porción eran tejidos asiáticos rotulados como sedas de Bretaña, de Francia y Cantabria; AGNL, Real Tribunal del Consulado de Lima, subsección Resguardo al comercio-Naufragios y arribadas, c. 137, doc. 932, f. 50.

${ }^{71}$ En 1773, el Tribunal del Consulado de Lima comprobó el ingreso por el puerto de El Callao de manufacturas de seda asiática y extranjera en navíos de registro españoles que vinieron por el Cabo de Hornos. La entrada salió a luz porque el tribunal dudaba de si dichos géneros estaban permitidos o no, y de si existía alguna norma fiscal para su gravamen; AGNL, Tribunal del Consulado, c. 11, doc. 476, f. 14.

${ }^{72}$ Algunas referencias sobre las imitaciones chinas fabricadas y consumidas en Europa pueden verse en Roche, A History; McKendrick, Brewer y Plumb, The Birth. 
segunda mitad del siglo xviII. Vale la pena aquí reproducir las palabras del contador de Madrid, Landazuri, en 1767. La crisis del galeón de Manila y la imposibilidad de que el mercado del Perú se viera abastecido de géneros asiáticos desde la costa novohispana se explican, en gran medida, por el proceso de "atlantización" del comercio asiático y sus imitaciones.

No puede negarse que las ropas y demás efectos que actualmente se traen de Filipinas según los últimos reglamentos de permisión tienen su avío y despacho en Nueva España, sin que no sólo resulte exceso que pueda dar lugar a su introducción en el Perú ni Tierra firme, sino es que no bastando al surtimiento de aquellas provincias, tiene acreditado la experiencia que es muy común el uso de las ropas que de esta clase [China] introducen clandestinamente los holandeses y otros extranjeros desde sus colonias, como también otras imitadas a aquéllas, pintadas en lienzo de lino, que los mismos extranjeros han inventado y van ya por el lícito canal de flotas y registros de Nueva España. ${ }^{73}$

Estamos en presencia de una transformación económica y cultural europea, en la cual las producciones occidentales se orientalizaron con el fin de dar una respuesta ampliada al mercado consumidor. La “atlantización” del comercio tendrá como componente significativo y novedoso lo que, en las fuentes de registro de barcos, de aduanas o de inventarios patrimoniales se conoce como bienes "chinescos" o "chinoiserie"; tejidos y cerámica europea producidos en serie con diseños y formatos orientales. ${ }^{74}$

73 Navarro García, "El comercio”, pp. 40-41.

74 Bonialian, China en la América colonial, pp. 119-181 y 196-246. 
Hemos notado que, durante el periodo colonial, los agentes mercantiles novohispanos, con el guiño cómplice de las autoridades y de manera ilegal, lograron que las telas y tejidos orientales venidos desde las islas Filipinas se rotularan como productos locales americanos. A partir de 1750 y luego con los procesos de emancipación americana fueron, sobre todo, el algodón de la India y los tejidos ingleses los que se rotularon como productos locales o asiáticos en el mercado mexicano. De tal manera, el fenómeno de las imitaciones y reproducciones europeas, en particular las emprendidas por los ingleses, no se limitaron a convertir sus productos en formato oriental, sino que se constituyeron en una estrategia económica general, para que los productos europeos, fueran una imitación o no, tuvieran despacho y venta en los mercados americanos. Desde finales del siglo xviII, el textil inglés que llegaba a México fue etiquetado como textil de producción local para evitar los impuestos que sufrían las mercaderías extranjeras en los puertos mexicanos. ${ }^{75}$

c) El textil inglés para el consumo social amplio en Hispanoamérica. El tercer factor, y el más importante, que nos permite comprender la desintegración de aquel principio de complementariedad se dio con el ingreso masivo de los tejidos de algodón ingleses. La historiografía demuestra con creces que los navíos neutrales de los ingleses y los que salieron desde las costas estadounidenses alcanzaron el Atlántico mexicano y el Caribe con grandes cargamentos de textiles europeos. Por ejemplo, en 1807, el valor de los tejidos extranjeros, mayormente ingleses, que se importaron por

75 Bernecker, Contrabando, pp. 69-70. 
Veracruz alcanzaban la extraordinaria suma de 10000000 de pesos, cuando dos años antes era de apenas $1000000 .^{76} \mathrm{Un}$ caso representativo de la composición de los cargamentos de estos barcos fue el del navío Mensajero, que por estos años descargó la mercadería en el puerto de Veracruz. Su valor total era de 1200000 reales y el grueso se compone de bretañas, zarazas, medias de algodón, muselinas y panas de algodón, todo inglés, pero también contaba en menores dimensiones con textiles de China. ${ }^{77} \mathrm{El}$ caso del Mensajero es un ejemplo típico de la transición comercial: la atlantización del comercio de textiles asiáticos pero que, poco a poco, se vieron desplazados por el algodón inglés. Con todo, la verdadera "inundación" de textiles británicos respondió al consumo social amplio, de trabajadores y trabajadoras urbanos y sectores medios de la población hispanoamericana. La producción textil local cayó con crudeza por todos los rincones manufactureros de Hispanoamérica. Junto con las porciones de telas, tejidos y cerámica asiática procedente del Pacífico, los textiles locales se vieron desplazados del mercado de consumo popular a causa de las bretañas y paños producidos en Inglaterra.

El enclave inglés en Jamaica sirvió de trampolín para la redistribución del tejido de algodón inglés en México, Centroamérica y el norte de Sudamérica. Hacia 1811 sus comerciantes instalados en las islas introducían 45000000 de pesos por concepto de manufactura textil a través de los circuitos del istmo de Darién y por todo el Pacífico por "haberlas acostumbrado a su consumo" en la región

\footnotetext{
76 Marichal, La bancarrota, pp. 206-207.

77 MARICHAL, La bancarrota, pp. 206-207.
} 
hispanoamericana. ${ }^{78}$ En 1818, Basilio de Arrillaga, asesor y secretario del Consulado de la Ciudad de México, señalaba que en Veracruz una vara de paño inglés costaba 10 reales, por lo que irónicamente se preguntaba: “¿cómo han de subsistir las fábricas de Querétaro, de México, de Guadalajara y de otros lugares valiendo los similares que allí se producen 18?". ${ }^{79}$ En Lima, Buenos Aires y Panamá sucedía un problema similar. En 1812, el editorial del periódico El Peruano apuntaba que el comercio y el consumo de tejidos de algodón ingleses daban cuenta del estancamiento de la producción textil local. Las consecuencias eran evidentes:

[... 50 mil familias que antes se ocupaban y mantenían en manufacturar tocuyos, bayetas de la tierra, bayetones y otras telas ordinarias de gran consumo, tanto en el virreinato como fuera de él, se vean hoy reducidas a la indigencia y a la desesperación [...] al país aniquilado del todo, sin que experimente otra ventaja que la aparente suma baratura y abundancia de los géneros de algodón ingleses. ${ }^{80}$

Estas últimas citas ponen al descubierto la posición proteccionista de los tradicionales consulados hispanoamericanos frente a la apertura indiscriminada de los productos extranjeros que circularon y se expandieron por cada

78 Correo de Londres de septiembre de 1817. Florescano y Castillo (eds.), Controversia, pp. 250-251 y 270.

79 De Arrillaga, Informe que dieron los señores José Ruiz de la Barcena; José María de Echabe y Gregorio Sáenz de Sicilia, prior y cónsules del Real Tribunal del Consulado de México, a Juan Ruiz de Apodaca, virrey, gobernador y capitán general de Nueva España (1818). FloresCANo y Castillo (eds.), Controversia, pp. 295-296.

${ }^{80}$ Florescano y Castillo (eds.), Controversia, p. 294. 
rincón de las incipientes naciones iberoamericanas. La última cita también sugiere el destino socialmente amplio del textil inglés. En la gobernación de Tucumán y Buenos Aires el reemplazo de la vestimenta local por la inglesa ya se advierte desde la segunda mitad del siglo xvirI. La tradicional indumentaria de los mestizos compuesta de ropa de la tierra, lienzos, cordellate y bayetas fue relevada por los lienzos, bretañas, angaripolas y otros textiles europeos y orientales que ingresaban a bajos precios. ${ }^{81}$ Para el periodo de las emancipaciones iberoamericanas, repasemos lo señalado por Halperin Donghi sobre los productos británicos importados en la sociedad rioplatense. Entre 1814 y 1819 la parte de los productos de consumo popular en la exportación británica al Plata osciló entre 60.3 y $42.3 \%$ (único año en que se ubicó por debajo de $50 \%$ ). ${ }^{82}$ Aunque no dispongamos de una cuantificación tan precisa para el caso de Chile, el trabajo de Llorca-Jaña muestra sólidas pruebas de que el algodón británico (particularmente las muselinas y el calicó) fue, por mucho, el rubro dominante de la canasta de importación destinada a la población popular de Chile en las primeras décadas del siglo XIX. ${ }^{83}$ Los casos de México, Buenos Aires y Chile expresan la pauta general de los cambios acaecidos en la cultura del consumo en todas las naciones iberoamericanas.

En suma, presenciamos una suerte de rotación de las líneas de circulación en el comercio global y continental.

81 Arcondo, El ocaso, pp. 103-227; Assadourian, El sistema, pp. 191207; Jumar, Le commerce, pp. 147-155.

82 Halperin Donghi, Guerra y finanzas, pp. 91 y 127-128.

${ }^{83}$ Llorca-Jaña, The British Textile, pp. 96-114. Hacia la cuarta década del siglo, las importaciones de textiles británicos representaban $40 \%$ de las importaciones para el consumo nacional de Chile. 
En términos de cultura económica del consumo, reiteramos una premisa fundamental: hasta 1750 el Atlántico abasteció de bienes suntuarios a Hispanoamérica y se encontraba condicionado por el comercio del Pacífico que proveía de mercaderías a un universo social amplio y divergente. A partir de la segunda mitad del siglo XviII y durante todo el XIX el Pacífico sufrió una “atlantización”, pues Europa tomará la función de abastecedor de bienes de consumo masivo sobre el mercado hispanoamericano, fenómeno que sería simultáneamente contrajo y frenó el desarrollo de la producción industrial local y nacional de los emergentes estados iberoamericanos. En 1815 se eliminó la relación transpacífica directa entre México y Filipinas realizada por el galeón de Manila. Las relaciones transpacíficas directas entre China y América se verán diluidas, reforzando un proceso de retraimiento y contracción a nivel global de la economía asiática. Estados Unidos se ubicará como escala intermedia de la mayor parte de los contactos mercantiles que México establecerá con China, una modalidad de relación que perdurará, cuando menos, hasta finales del siglo XIX.

EL LIBRE COMERCIO, APERTURA DE PUERTOS, REGIONALIZACIÓN ECONÓMICA, DESINTEGRACIÓN DEL MERCADO Y EL FIN DEL PODER DE LOS TRADICIONALES MONOPOLIOS CONSULARES

Ya hemos realizado numerosas referencias sobre los efectos que causaron en el mapa comercial hispanoamericano el libre comercio y las aperturas portuarias aplicadas por la España borbónica. En las pocas líneas que restan del trabajo valga una breve reflexión sobre otros cambios económicos 
y políticos que contribuyeron a la pérdida de la función central de la Ciudad de México (y sus comerciantes). Nos referimos a la regionalización-desintegración del mercado novohispano/mexicano y a las luchas de poder que se suscitaron entre los tradicionales consulados y los mercaderes regionales y locales en pleno ascenso. El modelo comercial colonial con epicentro en la Ciudad de México sólo podía funcionar si operaba la facultad monopólica de los consulados de la Ciudad de México y de Lima en la redistribución de los bienes extranjeros por los mercados internos de sus respectivos virreinatos. Si bien estas instituciones comerciales fueron la garantía para el sostenimiento de la Carrera de Indias, también se convirtieron en los principales patrocinadores para que aquel modelo funcionara.

Monopolizadores del circulante amonedado, los mercaderes integrantes de los consulados controlaron con exclusividad las importaciones, siendo, como hemos advertido, las ciudades de México y de Lima centros de acopio y redistribución de bienes. Los comerciantes menores regionales y locales de Nueva España contaron con muy poco margen de acción para participar en las ferias que se celebraban anualmente en Jalapa/Veracruz y en Acapulco. En gran medida, estos agentes mercantiles dependieron del suministro de mercancías extranjeras que les enviaban sus colegas desde la Ciudad de México para poder surtir su mercado local. Una situación similar ocurría hasta 1750 en el virreinato del Perú. Los comerciantes de Lima controlaban y monopolizaban las mercancías extranjeras importadas al virreinato, ya fueran las procedentes de México como las que eran canalizadas legalmente vía Portobelo desde España. Por ejemplo, hasta las primeras décadas del siglo Xviı los comerciantes de 
Chile y de Buenos Aires estaban, en última instancia, sujetos y dependientes de las cargas de bienes que se enviaban desde el centro de Lima. ${ }^{84}$

El escenario mercantil se transformó a partir de 1750. Las reformas borbónicas de la segunda mitad del siglo xviII reformularon las antiguas redes sociales que se habían tejido entre México y Perú por el Pacífico. También se reconstruyeron las redes comerciales internas trazadas por la Nueva España, debilitando el papel central de los comerciantes de la Ciudad de México. Los tradicionales mecanismos apoyados en el control de la circulación de la plata dejaron de funcionar $\mathrm{y}$, como efecto de arrastre, los propios almaceneros novohispanos perdieron el manejo de las importaciones y la intervención-regulación que generaban en la oferta y la demanda sobre el mercado. ${ }^{85}$ El fenómeno de regionalización y fragmentación económica que se vivió en México y en el resto de Hispanoamérica en las últimas décadas del siglo XVIII originó un bloqueo de los tradicionales circuitos mercantiles interregionales. Las consecuencias de estos cambios nos llevan a reiterar algunas premisas: la gravitación de

${ }^{84}$ La afirmación no supone en lo absoluto desconocer el contrabando y los recurrentes permisos comerciales de que gozaba Buenos Aires desde el siglo Xvir, práctica que beneficiaba a los comerciantes porteños en detrimento de los limeños. Sin embargo, nadie podría dudar que, al menos hasta mediados del siglo XviII, los limeños mantuvieron la capacidad de mantener su predominio comercial en el virreinato. En el caso de Chile, ya hemos mencionado en las primeras páginas del trabajo la controversia historiográfica en torno al momento en que logró liberarse de la dependencia del comercio peruano.

${ }^{85}$ La historiografía demuestra con creces que, al perder gran parte del poder mercantil, los integrantes del Consulado se replegaron hacia otras actividades económicas, como la agricultura, la minería y las finanzas. Pérez Herrero, “Actitudes”, pp. 97-182. 
los comerciantes de la Ciudad de México decayó, al verse cuestionado su poder político por los nuevos comerciantes surgidos al calor del libre comercio. Desde entonces, su papel como punto conector entre las economías del Atlántico y del Pacífico se fracturó. En términos espaciales, la capital perdía relevancia como "corazón" redistributivo de mercancías extranjeras por todas las plazas del virreinato.

El libre comercio, junto con la apertura de nuevos puertos al tráfico externo, ofreció nuevas oportunidades a los mercados internos regionales. Las plazas mercantiles iniciaron un abastecimiento directo de bienes gracias a la presencia de los comerciantes extranjeros en las costas, sin necesidad de que intervinieran los comerciantes de la Ciudad de México. La práctica de "tierra adentro", la frecuente movilidad de los agentes del interior hacia las tiendas, almacenes y depósitos ubicados en la Ciudad de México durante el funcionamiento del modelo precedente, comenzó a ser una estrategia económica excepcional. Desde la segunda mitad del siglo XVIII, para disponer de mercancías europeas y de Asia, el agente regional, al tener disponibilidad de plata, se abasteció desde los diferentes puertos autorizados. En 1792, el Consulado de la Ciudad de México lo manifestaba muy claramente:

[...] el principal motivo del atraso del comercio de México consiste en que los mercaderes de tierra adentro no vienen ya a surtirse a esta Capital de lo que necesitan para el giro de sus comercios, como lo ejecutaban antes, sino que bajan en derechura a Veracruz para el efecto. Y este hecho se comprobará con evidencia si se cotejan las pocas Guías que se despachan en Veracruz con destino a esta capital, con las muchas que se 
dirigen en derechura a los lugares de la tierra adentro, de modo que en el día sólo vienen a México lo que necesita para su consumo, careciendo los comerciantes de la capital de las utilidades que antes le rendían los negocios de la tierra adentro. ${ }^{86}$

El movimiento "tierra adentro" no debe confundirse con las “internaciones” peninsulares. Si a partir de la segunda mitad del siglo xviıI, la circulación de agentes locales hacia la capital novohispana se tornaba una práctica extraña, las “internaciones” peninsulares fueron cada vez más frecuentes y regulares. Con legislación a su favor, los comerciantes españoles que llegaban con sus navíos de registro o con la propia flota de Veracruz penetraban sistemáticamente en los mercados regionales, rompiendo con el blindaje monopólico que hasta entonces había logrado imponer el Consulado de la Ciudad de México.

En el espacio del Perú se vivió un proceso muy similar. La caída de las ferias de Portobelo desmanteló la regla por la cual el comisionista peninsular debía esperar y limitar su acción comercial en el lugar y al tiempo circunscripto de la celebración de la feria. Cuando se inauguró la ruta por el Cabo de Hornos y se liberaron al tráfico directo los puertos de Buenos Aires y del Pacífico sudamericano, el mercader peninsular se introdujo a los mercados internos regionales para vender sus productos. El Consulado de Lima veía cuestionada su facultad monopólica de redistribución de bienes por el virreinato. Ahora, el agente español podía negociar directamente con el mercader local, evitando la mediación de los mercaderes

86 "Representación del Consulado al Virrey Revillagigedo, apoyando la petición de los comerciantes, 2 de enero de 1792". Florescano y CASTILlo (eds.), Controversia, pp. 253-254. 
limeños. Si bien requiere mayor fundamentación, es posible suponer que las internaciones españolas, institucionalizadas y protegidas por el reformismo borbónico, se hayan constituido en el antecedente inmediato que permitió a los comerciantes británicos y de otras naciones europeas movilizarse, instalarse y dominar el mercado de bienes y plata por Hispanoamérica durante las primeras décadas del siglo XIX.

Decíamos en páginas previas que a partir de la segunda mitad del siglo XVIII las importaciones de bienes extranjeros a la Ciudad de México se limitaron al consumo interno de la plaza capitalina. El sobreabasto de mercaderías, principio rector del anterior modelo comercial, había dejado de funcionar. La falta de excedente de productos en la Ciudad de México podría comprenderse a partir del abastecimiento directo que los europeos ofrecían a los comerciantes regionales por cada puerto autorizado. De tal manera, los principales beneficiarios de las políticas borbónicas de libre comercio y posteriormente del liberalismo económico promovido por los ingleses y estadounidenses fueron, ante todo, las élites económicas locales que cuestionaban el poder tradicional de la Ciudad de México y de Lima. Así, la apertura de nuevas rutas marítimas y puertos en ambas costas de Iberoamérica crearon verdaderos polos de arrastre costeros que suministraban productos extranjeros destinados a los centros de concentración demográfica y mercantil de relevancia. Lo que ocurrió para el caso de Veracruz (que hemos visto en la mención última) podría extenderse hacia la región del Pacífico y Sudamérica. Ya mencionamos el crecimiento del comercio libre y directo que se practicó desde el puerto de San Blas, surgidero por donde se alentó el proceso de autonomía económica de la ciudad de Guadalajara y de Tepic en relación 
con la Ciudad de México. Para el caso de Sudamérica, sobresalen Buenos Aires y Santiago de Chile.

La fracturación de grandes zonas económicas a partir de la segunda mitad del siglo xviII anticipó la configuración de nuevas demarcaciones político administrativas. Piénsese en las intendencias y en perspectiva mayor en los estados nacionales. El declive de la capacidad estructurante de la Ciudad de México y de Lima fue paulatino y con rasgos particulares. Estas diferencias posiblemente puedan explicar los elementos disímiles de las entidades políticas republicanas surgidas en México y en el Perú. ${ }^{87}$ Sin embargo, no creo que debamos opacar los elementos y procesos comunes que se vivieron por toda Hispanoamérica.

La fragmentación económica y el descenso de la Ciudad de México y de Lima como espacios estructurantes de grandes zonas alentaron la institucionalización de corporaciones mercantiles por cada una de las regiones que se veían beneficiadas de la política de libre comercio borbónica. En este marco, deberíamos comprender la "catarata" de fundaciones consulares: Manila (1769), Caracas (1793), Guatemala (1793), Buenos Aires (1794), Montevideo (1794), La Habana (1794), Veracruz (1795), Santiago de Chile (1795), Guadalajara (1795), Cartagena de Indias (1784) y, más tarde, Puebla (1821). La institucionalización de los intereses de las élites regionales manifiestan al menos tres fenómenos que

87 Según la historiadora Cristina Mazzeo, la impronta del liberalismo fue más notoria en el caso mexicano que en el peruano. En el caso del Consulado de Lima, su poder perduró por mucho más tiempo que el de la Ciudad de México, hasta el punto de haber sido el antecedente más concreto de los organismos estatales del país para la época independiente. MAzzeo, Gremios mercantiles. 
ocurrieron simultáneamente: 1) el descenso de la Ciudad de México y de Lima como polos económicos y políticos que articulaban grandes espacios económicos; 2) la concentración de capitales y bienes en las corporaciones mercantiles locales en ascenso, gracias al apoyo, negociación y alianza con los mercaderes europeos (primero con los peninsulares y, más tarde, con los ingleses y estadounidenses); 3) los puertos como unidades costeras generadoras de mercados locales y promotoras del desarrollo de la política de libre comercio.

La fragmentación y regionalización mercantil, con la consecuente división político administrativa, nos resulta relevante para comprender aquellas titánicas navegaciones transcontinentales que desde finales del siglo XviII realizaron los navíos ingleses y estadounidenses saliendo desde Europa o desde Boston, costeando cada puerto del Atlántico, cruzando el Cabo de Hornos y ascendiendo por cada surgidero del Pacífico mexicano (mapa 2). La política de reforma administrativa aplicada por el gobierno borbónico (como era el caso de las intendencias), y posteriormente las luchas y conflictos generados por las emancipaciones hispanoamericanas, profundizaron los inconvenientes surgidos en el periodo borbónico para las conexiones de los mercados regionales, desvaneciendo la integración mercantil de la Nueva España y el Perú hasta la primera mitad del siglo xviII. En el caso mexicano, la desintegración y la autarquía del mercado perduró y se agudizó durante el segundo cuarto del siglo XIX. ${ }^{88} \mathrm{El}$ sistema de transporte interno

${ }^{88}$ CÁrdenas, Cuando se originó el atraso, pp. 72-90. Hacia 1830 la situación de caos económico continuaba presente. Véase al respecto Tutino, "El debate", pp. 1119-1124. 
mexicano colapsó, aumentando los costos de transporte, fragmentando aún más el mercado interno y aislando las diversas regiones del país. ${ }^{89}$

Recapitulemos lo expuesto en una síntesis. En el primer apartado se expusieron las principales líneas y elementos que dieron vida al modelo de comercio con epicentro en la Ciudad de México y el Pacífico. Se propuso que dicho tejido se mantuvo vigente hasta mediados del siglo XviII, gracias al monopolio comercial para la importación de bienes ultramarinos y la exportación de metálico que detentaban los grandes mercaderes de la Ciudad México y de Lima por Hispanoamérica. Su quiebre estructural y definitiva descomposición aparecieron con las medidas borbónicas de apertura portuaria y libre, que dieron vía libre a la intervención de los agentes hispánicos por el Pacífico y, en particular, a la formalización de la ruta transoceánica del Cabo de Hornos. El nuevo circuito de larga distancia que desde 1740-1750 comunicó a Europa con el Pacífico y el Oriente asiático generó un efecto disruptivo en la posición geopolítica y económica privilegiada que, hasta entonces, había conservado México. Su posición de centro gravitante en la economía colonial hispanoamericana, operado por medio de su papel de entronque Acapulco/Ciudad de México/Veracruz declinó, cayendo en la inactividad hasta y durante las guerras de independencia.

La disolución de la centralidad mexicana en el comercio continental y global se vio acompañada y en íntima relación con la "atlantización” del Pacífico. La “atlantización” del Pacífico lo entendemos aquí como su europeización (primero

89 ORTIZ, Caminos y transportes, pp. 143-182. 
operada por España y luego por Inglaterra). Este gran fenómeno histórico rompió la marcada identidad indiana que hasta 1750 gozó el Pacífico y erosionó también su característica principal: autonomía. Podríamos sintetizar el fenómeno de la siguiente manera: hasta 1750 el Atlántico se vio "pacificado" en razón de que el área marítima occidental hispanoamericana influyó - ya sea para alentar (México) o condicionar (Panamá) - los grandes flujos trasatlánticos del comercio monopólico español. Luego de esa fecha, el Pacífico se "atlantizó”: se vio determinado por los circuitos del Atlántico controlados por los europeos, iniciando su proceso de “europeización”. El fenómeno descrito contribuyó a la decadencia del galeón de Manila, a la intromisión de agentes, compañías y barcos europeos $\mathrm{y}$, fundamentalmente, a la conquista europea del mercado consumidor peruano/sudamericano, que desplazó a la Ciudad de México como polo proveedor de bienes.

Estaríamos en presencia de un cambio de paradigma mercantil sobre la inserción de Hispanoamérica en el concierto imperial y global; una transformación que se mantuvo y trascendió los cambios políticos generados por las revoluciones de independencia. Más aún, éstas vinieron a fortalecer un fenómeno mercantil preexistente, originado durante la segunda mitad del siglo xviII. De tal manera, más que discontinuidades en las relaciones comerciales, las independencias latinoamericanas contribuyeron a profundizar - eso sí, con nuevos agentes - un proceso anterior. Entre 1750 y 1790 fueron predominantemente navíos de compañías peninsulares los que tomaron el dominio de las aguas del Pacífico. Desde los últimos años del siglo xviII serán los ingleses y los estadounidenses los agentes económicos fundamentales que dinamizaron y controlaron el Pacífico. 
La transformación de las relaciones económicas no sólo se explicaría desde el plano de los circuitos y rutas. La descomposición del modelo cuyo centro era la Ciudad de México obedeció también a cambios registrados en el proceso productivo y en la cultura del consumo por Hispanoamérica. En aquel tejido, el eje transpacífico de bienes asiáticos, junto con la producción local de textiles y lozas, respondieron al consumo masivo y popular. La vía trasatlántica de bienes europeos se dirigió especialmente a responder a la demanda de productos lujosos y terminados solicitados por un reducido círculo español y criollo. A partir de 1750, con el fenómeno de la "atlantización", el consumo socialmente masivo comenzó a proveerse desde Europa, con la movilización de bienes asiáticos, de sus imitaciones europeas y, en especial, del textil de algodón de la India y luego inglés. Esta canasta amplia y variada de productos propició una decadencia de la producción manufacturera local, sector económico que, en el periodo colonial, fue relativamente tolerado y en ciertos momentos promocionado por la corona española para responder a la demanda de los sectores medios y pobres del universo hispanoamericano.

Por otra parte, y para finalizar, nos atrevemos a proponer una periodización de larga duración respecto a los ejes transoceánicos americanos; esos nudos o conductos que comunicaron, condicionaron o estimularon la relación de los flujos del Atlántico y del Pacífico. Hasta 1750 fue la Ciudad de México, con sus brazos hacia Acapulco y Veracruz, el eje geopolítico y económico dominante del continente americano. En él se integró el espacio peruano para conformar un gran eje geohistórico del Pacífico que, si bien fue considerado marginal por el poder peninsular, resultó 
de gran relevancia en la evolución del comercio imperial y global. De ahí, la definición "la centralidad de lo marginal" que brindamos en trabajos anteriores en referencia al Pacífico hispanoamericano. ${ }^{90}$ Desde 1750 hasta 1840 , se erigió como nudo de tránsito prioritario el Cabo de Hornos, desplazando a la Ciudad de México como eje transcontinental y posición política privilegiada. El paso por el estrecho austral se posicionó como la ruta más transitada en la movilización de los europeos y estadounidenses para conectar las economías de ambos océanos. En este contexto, el comercio del Pacífico se vio subsumido, condicionado, a la economía mercantil europea, perdiendo esa función central de que gozó hasta 1750. Ahora, el Pacífico sufría una efectiva posición de periferia en la economía global europea. Finalmente, luego de 1840, etapa que aquí no se ha analizado, el eje de Panamá será la vía privilegiada para que los europeos y los estadounidenses accedan a la riqueza de oro de California y al comercio con China. En este marco de relaciones comerciales globales se verá inserto el Pacífico mexicano continuando en una clara posición periférica.

\section{SIGLAS Y REFERENCIAS}

AGI Archivo General de Indias, Sevilla, España.

AGN Archivo General de la Nación, Ciudad de México.

AGNL Archivo General de la Nación de Lima, Perú.

AHCIS Archivo de los Jesuitas de la Provincia de Cataluña, España.

90 Bonialian, El Pacífico. 
Álvarez, Luis Alonso, "El impacto de las reformas borbónicas en las redes comerciales. Una visión desde el Pacífico hispano, 1762-1815”, en Ibarra y Valle Pavón (coords.), 2007, pp. 187-213.

Arcondo, Aníbal, El ocaso de una sociedad estamental. Córdoba entre 1700-1760, Universidad Nacional de Córdoba, Argentina, 1992.

Assadourian, Carlos Sempat, El sistema de la economía colonial, Lima, Instituto de Estudios Peruanos, 1982.

Bernabeu, Salvador, El Pacífico ilustrado: del lago español a las grandes expediciones, Madrid, Mapfre, 1992.

Bernecker, Walter, Contrabando. Ilegalidad y corrupción en el México del siglo XIX, México, Universidad Iberoamericana, 1994.

Bonialian, Mariano, China en la América colonial. Bienes, mercados, comercio y cultura del consumo desde México hasta Buenos Aires, México, Buenos Aires, Instituto de Investigaciones Dr. José María Luis Mora, Biblos, 2014.

Bonialian, Mariano, El Pacífico hispanoamericano. Política y comercio asiático en el Imperio español (1680-1784). La centralidad de lo marginal, México, El Colegio de México, 2012.

Bonialian, Mariano, "La ropa de la China desde Filipinas hasta Buenos Aires. Circulación, consumo y lucha corporativa, 1580-1620", en Revista de Indias, Madrid, Instituto de Historia [en prensa].

Bonialian, Mariano, "México: epicentro semiinformal del comercio hispanoamericano (1680-1740)", en América Latina en la Historia Económica, México, 35 (2011), pp. 7-27.

Bonialian, Mariano, “La 'contratación de la China' por la América colonial a principios del siglo Xvir. La mirada de Francisco Valverde de Mercado. Gobernador de Panamá", en Boletín del Instituto de Historia Argentina y Americana "Dr. Emilio Ravignani", Tercera serie, 40 (2014), pp. 11-40. 
Bonilla, Heraclio, "La coyuntura comercial del siglo xix en el Perú", en Desarrollo Económico, 12: 46 (1972), pp. 305-331.

Busto Ibarra, Karina, "El espacio del Pacífico mexicano: puertos, rutas, navegación y redes comerciales, 1848-1927", tesis de doctorado en historia, México, El Colegio de México, 2008.

CÁrdenas Sánchez, Enrique, Cuando se originó el atraso económico de México. La economía mexicana en el largo siglo XIX, 1780-1920, Madrid, Biblioteca Nueva, 2003.

Carmagnani, Marcello, Las islas de lujo. Productos exóticos, nuevos consumos y cultura económica europea, 1650-1800, Madrid, Ambos Mundos, Marcial Pons, 2012.

Carmagnani, Marcello, Los mecanismos de la vida económica en una sociedad colonial. Chile (1680-1830), Santiago de Chile, Diвam, Centro Barros Arana, 2000.

Cavieres, Eduardo, "Comercio, diversificación económica y formación de mercados en una economía en transición. Chile en el siglo XIX", en IRIGOIN y SCHMIT (eds.), 2003, pp. 93-110.

Chávez Orozco, Luis Controversia que suscitó el comercio de Nueva España con los países extranjeros: 1811-1821, México, Banco Nacional de Comercio Exterior, 1959.

CONTRERAs, Carlos, El sector exportador de una economía colonial: la costa del Ecuador entre 1760 y 1820, Quito, Facultad Latinoamericana de Ciencias Sociales, 1990.

Contreras Valdez, Mario, Nayarit. Historia breve, México, El Colegio de México, Fondo de Cultura Económica, Fideicomiso Historia de las Américas, 2010.

Cross, Harry, "South American Bullion Production and Export 15501750”, en Richards (ed.), 1983, pp. 397-423. 
Dane, Hendrik, "Primeras relaciones diplomático-comerciales entre Alemania y México", en Historia Mexicana, xvir: 1 (65) (jul.-sep. 1967), pp. 72-102.

Findlay, Ronald y Kevin O'Rourke, Power and Plenty: Trade, War and the World Economy in the Second Millennium, Princeton, Princeton University Press, 2007.

FISHER, John, El comercio entre España e Hispanoamérica (1797-1820), Madrid, Banco de España, 1993.

Flores GuZmán, Ramiro, "Los balleneros anglonorteamericanos y la apertura comercial del Pacífico sur a fines de la época colonial (17901820”), en Histórica, 34 (2) (2010), pp. 63-98.

Florescano, Enrique y Fernando Castillo (eds.), Controversia sobre la libertad de comercio en Nueva España, 1766-1818, México, Instituto de Comercio Exterior, t. II, 1975.

Flynn, Dennis y Arturo Giráldez, "Los orígenes de la globalización en el siglo xvi”, en Hausberger e Ibarra (coords.), 2014, pp. 29-76.

Ganci, Massimo y Ruggiero Romano, Gobernare il mondo. L'imperio spagnolo dal XV al XIX secolo, Palermo, Università di Palermo, 1991.

García Baquero, Antonio, Cádiz y el Atlántico (1717-1778), Sevilla, Escuela Hispanoamericana de Sevilla, 1976, vol. 1.

Guerra Martinière, Margarita, Cristina Ana Mazzeo de Vivó, Denisse Rouillon Almeida (eds.), Historias compartidas: economía, sociedad y poder, siglos XVI-XX, Lima, Pontificia Universidad Católica del Perú, 2007.

Halperin Donghi, Tulio, Guerra y finanzas en los orígenes del Estado argentino (1791-1850), Buenos Aires, Prometeo Libros, 2005.

Hausberger, Bernd y Antonio Ibarra (coords.), Oro y plata en los inicios de la economía global: de las minas a la moneda, México, El Colegio de México, 2014. 
Humboldt, Alexander von, Ensayo político sobre el reino de la Nueva España, México, Compañía General de Ediciones, 1953.

Ibarra, Antonio, "Redes de circulación y redes de negociantes en Guadalajara colonial: mercado, élite comercial e instituciones", en Historia Mexicana, LVI: 3 (223) (ene.-mar. 2007), pp. 1017-1041.

Ibarra, Antonio y Guillermina del Valle Pavón (coords.), Redes sociales e instituciones comerciales en el imperio español, siglos XVII a $X I X$, México, Instituto de Investigaciones Dr. José María Luis Mora, Universidad Nacional Autónoma de México, 2007.

Irigoin, Alejandra y Roberto Schmit (eds.), La desintegración de la economía colonial: comercio y moneda en el interior del espacio colonial, 1800-1860, Buenos Aires, Biblos, 2003.

Jumar, Fernando, Le commerce atlantique au Río de la Plata, 16801778, Villeneuve d'Ascq, Presses Universitaires du Septentrion, t. I, 2002.

Lamikiz, Xabier, Trade and Trust in the Eighteenth-Century Atlantic World, Spanish Merchants and their Overseas Networks, Gran Bretaña, The Royal Historical Society, The Boydell Press, 2010.

León, Jorge, “Comercio por el Mar del Sur o Pacífico, 1790-1800”, en Revista de Historia, 43 (2001).

León de Borja, Dora y Adam Nagy SzÁsdi, "El comercio de cacao de Guayaquil”, en Revista de Historia de América, 57-58 (1964), pp. 1-50.

Lerdo de Tejada, Miguel, Comercio exterior de México desde la conquista hasta boy, nota preliminar de Luis Córdoba, México, Banco Nacional de Comercio Exterior, 1967.

Llorca-Jaña, Manuel, The British Textile Trade in South America in the Nineteenth Century, Cambridge, Cambridge University Press, 2012. 
López Cancelada, Juan, "Ruina de la Nueva España si se declara el comercio libre con los extranjeros, Cádiz, 1811”, en Chávez Orozco, 1959, pp. 79-120.

Marichal, Carlos, La bancarrota del virreinato, Nueva España y las finanzas del Imperio, 1780-1810, México, El Colegio de México, Fideicomiso Historia de las Américas, Fondo de Cultura Económica, 1999.

MaYo, John, "Imperialismo de libre comercio e imperialismo informal en la costa oeste de México durante la época de Santa Ana”, en Historia Mexicana, xL: 4 (160) (abr.-jun. 1991), pp. 672-696.

Mazzeo, Cristina, "El circuito comercial del Pacífico. Convergencia y divergencia entre dos ciudades portuarias: El Callao y Valparaíso, entre la Colonia y la República”, en Guerra Martinière, Mazzeo de Vivó y Rouillon Almeida (eds.), 2007, pp. 421-453.

Mazzeo, Cristina, Gremios mercantiles en las guerras de Independencia. Perú y México en la transición de la Colonia a la República, 1740-1840, Lima, Instituto de Estudios Peruanos, Banco Central de Reserva del Perú, 2012.

McKendrick, Neil, John Brewer y John Plumb, The Birth of a Consumer Society. The Comercialization of Eighteenth Century England, Bloomington, Indiana University Press, 1982.

Meyer, Jean, Breve historia de Nayarit, Breve historia de los Estados, México, El Colegio de México, Fideicomiso Historia de las Américas, Fondo de Cultura Económica, 2008.

Miño Grijalva, Manuel, El cacao Guayaquil en Nueva España, 17711812 (política imperial, mercado y consumo), México, El Colegio de México, 2013.

Mola, Alfonso Marina y Carlos Martínez Shaw, "El Galeón de Manila", en La aventura de la historia, Madrid, Arlanza, 2000, pp. 58-65. 
MonsÉGur, Jean de, Las nuevas memorias del capitán Jean de Monségur, en Jean Pierre Berthe (ed.), México, Universidad Nacional Autónoma de México, 1994.

Moutoukias, Zacarías, Contrabando y control colonial en el siglo XVII: Buenos Aires, el Atlántico y el espacio peruano, Buenos Aires, Centro Editor de América Latina, 1988.

Navarro García, Luis, "El comercio interamericano por la Mar del Sur en la Edad Moderna”, en Revista de Historia, 23 (1965), pp. 11-55.

Ortiz Hernán, Sergio, Caminos y Transportes en México. Una aproximación socioeconómica: fines de la Colonia y principios de la vida independiente, México, Fondo de Cultura Económica, 1994.

Parrón Salas, Carmen, De las Reformas borbónicas a la República: el Consulado y el comercio marítimo de Lima, 1778-1821, Murcia, España, Academia General del Aire, 1995.

Pereira Salas, Eugenio, Los primeros contactos entre Chile y los Estados Unidos, 1778-1809, Santiago de Chile, Andrés Bello, 1971.

Pérez Herrero, Pedro, “Actitudes del Consulado de México ante las reformas comerciales borbónicas (1718-1765)", en Revista de Indias, XLIII: 171 (1983), pp. 77-182.

Richards, John (ed.), Precious Metals in the Later Medieval and Early Modern World, Durham, Carolina Academic Press, 1983.

Roche, Daniel, A History of Everyday Things. The Birth of Consumption in France, 1600-1800, Nueva York, Cambridge University Press, 2003.

Schurz, William Lytle, "The Spanish Lake”, en The Hispanic American Historical Review, 5: 2 (1922), pp. 181-194.

Spate, Oskar, The Pacific since Magellan, vol. I. The Spanish Lake, Londres, Cromm Helm, 1979. 
Suárez, Margarita, Desafíos transatlánticos. Mercaderes, banqueros y el Estado en el Perú virreinal, 1600-1700, Lima, Fondo de Cultura Económica, 2001.

Tutino, John, "El debate sobre el futuro de México: en busca de una nueva economía, 1830-1845”, en Historia Mexicana, Lxv: 3 (259) (ene.mar. 2015), pp. 1119-1192.

UlLOA, Bernardo, Restablecimiento de las fábricas y comercio español (1740), Madrid, Instituto de Estudios Fiscales, 1992.

Valdés Lakowsky, Vera, De las minas al mar. Historia de la plata mexicana en Asia, 1565-1834, México, Fondo de Cultura Económica, 1987.

VIla Vilar, Enriqueta, "Las ferias de Portobelo: apariencia y realidad del comercio con Indias", en Anuario de Estudios Americanos, xxxix (1982), pp. 275-340.

Villalobos, Sergio, Comercio y contrabando en el Río de la Plata y Chile, 1700-1811, Buenos Aires, Universidad de Buenos Aires, 1965.

Vives AnZacot, Pedro, "El Pacífico español: frontera imperial, frontera americana”, en Ganci y Romano (coords.), 1991, pp. 245-257.

VRIEs, Peer, State, Economy and the Great Divergence: Great Britain and China, 1680s-1850s, Londres, Bloomsbury Academic, 2015.

Yuste, Carmen, Emporios transpacificos. Comerciantes mexicanos en Manila, 1710-1815, México, Universidad Nacional Autónoma de México, 2007. 
